\title{
Does watching TV make us happy?
}

\begin{abstract}
Watching TV is a major human activity. Because of its immediate benefits at negligible immediate marginal costs it is for many people tempting to view TV rather than to pursue more engaging activities. As a consequence, individuals with incomplete control over, and foresight into, their own behavior watch more TV than they consider optimal for themselves and their well-being is lower than what could be achieved. We find that heavy TV viewers, and in particular those with significant opportunity cost of time, report lower life satisfaction. Long TV hours are also linked to higher material aspirations and anxiety.
\end{abstract}




\title{
DOES WATCHING TV MAKE US HAPPY?
}

\author{
Bruno S. Frey ${ }^{\mathrm{a}}$, Christine Benesch ${ }^{\mathrm{a}}$, and Alois Stutzer ${ }^{\mathrm{b}}$
}

July 05, 2006

\begin{abstract}
Watching TV is a major human activity. Because of its immediate benefits at negligible immediate marginal costs it is for many people tempting to view TV rather than to pursue more engaging activities. As a consequence, individuals with incomplete control over, and foresight into, their own behavior watch more TV than they consider optimal for themselves and their well-being is lower than what could be achieved. We find that heavy TV viewers, and in particular those with significant opportunity cost of time, report lower life satisfaction. Long TV hours are also linked to higher material aspirations and anxiety.
\end{abstract}

JEL classification: D12, D91, I31, J22

Keywords: Life satisfaction, mispredicting utility, revealed behavior, self-control problem, TV consumption

\footnotetext{
a Institute for Empirical Research in Economics, University of Zurich, Winterthurerstrasse 30, $\mathrm{CH}-8006$ Zurich, Switzerland. Phone: +41-44-634 3728, fax: +41-44-634 4907.

b Department of Economics, University of Basel, Petersgraben 51, CH-4003 Basel, Switzerland. Phone: +41-61-267 3361, fax: +41-61-267 3340.

Emails: bsfrey@iew.unizh.ch, christinebenesch@access.unizh.ch, alois.stutzer@unibas.ch.

The first and third authors are also associated with CREMA - Center for Research in Economics, Management and the Arts. We are grateful for helpful remarks from Matthias Benz, Giacomo Corneo, Carol Graham, Jonathan Gruber, Silke Humbert, Simon Lüchinger, Susanne Neckermann, Martha Starr, Fred Zimmerman and the co-editor Daniel Read.
} 


\section{Does Watching TV Make Us Happy?}

Watching TV is a very important activity, carried out by most people in the majority of countries. On average, people in Europe spend 226 minutes watching TV a day, in the United States TV viewing, on average, amounts even to 297 minutes per day (IP Germany 2005). In many countries nowadays, watching TV occupies on average almost as much time as working. As it is a totally voluntary, freely chosen activity, it seems obvious that people enjoy it, because they would not do it otherwise. They are more satisfied with having the opportunity to watch TV to the extent they do rather than watching less TV or none at all.

This implication is shared by standard neoclassical economic theory. Individuals are assumed to know best what provides them with utility and are free to choose the amount of TV consumption that suits them best. By revealed preference, it follows from the fact that individuals watch so much TV as has been empirically observed that it provides them with considerable utility.

Recent developments, particularly in behavioral economics, cast doubt on this conclusion. The theory of revealed preference has been questioned (see, for instance, Sen 1982; 1995): it is, in general, not possible to infer the utility produced by observing behavior, because individuals do not always act rationally. More concretely, anomalies and biases in behavior have been identified (e.g. Thaler 1992), which undermine the direct link between observed behavior and the utility gained. Individuals may also be subject to habits which they do not have fully under control. They may consume some goods, such as drugs, alcohol or tobacco to a greater extent than they find to be good for themselves. They are subject to a self-control problem (e.g. Schelling 1984), again interfering with the direct relationship proposed by revealed preference theory. As Gruber and Mullainathan (Gruber and Mullainathan 2005) empirically show, (predicted) smokers, according to their own evaluation, consider themselves to be better off if smoking was restricted by a tax. Finally, individuals may systematically mispredict the utility derived from future consumption (e.g. Loewenstein and Schkade 1999; Loewenstein et al. 2003). In particular, happiness research (for a survey, see Frey and Stutzer 2002a; b; Layard 2005) has empirically shown that individuals overestimate the utility of future income (e.g. Easterlin 2001), at the same time as they underestimate the utility of personal interactions (Frey and Stutzer 2004). The consumption decisions made by individuals are systematically distorted according to their own evaluations. 
This paper studies the strong notion that TV viewing is a case in which the theory of revealed preference does not fully apply: many people watch more TV than they consider good for themselves. The extent of TV viewing is not generally utility maximizing.

The case for mistakes in TV consumption choice can be formulated within a systematic framework: Individuals are subject to a self-control problem, mainly induced by the fact that watching TV offers immediate benefits (e.g. entertainment and relaxation) at very low immediate marginal costs. Many costs (e.g. not enough sleep, underinvestment in social contacts, education or career) are only experienced in the future. Individuals with time inconsistent preferences are therefore unable to adhere to the amount of TV viewing they planned or which, in retrospect, they would consider optimal for themselves. This tendency is aggravated when people mispredict future costs because they underestimate utility from socializing and neglect changes in preference due to TV consumption. Extensive TV viewing is, according to this alternative view, the result of mispredicting utility and a self-control problem, leading to a lower level of individual utility than what could be achieved.

It is very difficult to discriminate between the view of optimal TV watching and the view of over-consumption based on observed behavior. How is it possible to assess from the outside whether four hours TV viewing a day are too much and are actually regretted by the consumer? Neither is there conclusive information about optimal consumption behavior in TV viewers' reaction to price changes. Whether or not people consistently allocate their time and income, they will react to relative price changes in the consumption of TV watching in the direction predicted by standard economics. Only if people adhere to external commitment devices that limit their future choice sets, their observed behavior indicates that they are subject to self-control problems. Yet, there exists only anecdotal and no systematic evidence for the use of such self-commitment devices (e.g. people put an uncomfortable chair in front of their TV or cancel their cable subscription in order not to watch too much TV or even get rid of their TV).

We pursue a completely different approach and propose data on subjective well-being to study whether people make systematic mistakes in their choice of time devoted to TV watching. Life satisfaction or reported subjective well-being can serve as a proxy for experienced utility as suggested by happiness research. Based on this methodology, it is in principle possible to study whether higher TV consumption lowers an individual's utility or well-being as suggested by the pessimistic view about people's TV watching. In our analysis, 
we explore to what extent standard information on individual TV consumption and subjective well-being can inform the debate.

The empirical analysis studies data from the first wave of the European Social Survey. This is an exceptionally rich data set providing information for more than 42,000 people from 22 different countries for 2002/03. The baseline econometric estimate lends support to the hypothesis of over-consumption: excessive TV viewers, on average, report lower life satisfaction. This negative correlation holds even after controlling for a large number of covariates of individual well-being.

We are aware that this correlation does not imply causation. The causality issue can neither be resolved with an extensive set of control variables in a multiple regression analysis nor with panel data. Instead one would want to study large scale changes in people's opportunities to watch TV that are set from outside. We are not aware that suitable data, such as a natural experiment, exist. Instead two other aspects of the interrelation between TV consumption and subjective well-being are studied: (i) Whether the utility costs of extensive TV consumption depend on the opportunity cost of time. (ii) Whether TV viewing affects people's preferences and beliefs.

We find that particularly individuals with time constraints, who watch TV for many hours, report lower life satisfaction and that watching TV is positively related to people's material aspirations, as well as to anxiety levels, and negatively related to their financial satisfaction, to their trust in others, as well as to the perceived relative frequency of social activities. Section I of this paper discusses TV viewing as a major activity in modern life.

Section II develops the basic testable hypothesis. The following section III presents the data and section IV gives the results of the basic econometric estimates and integrates them into the existing literature on TV and happiness. The next section deals with the possibility of reverse causation and addresses the role of opportunity costs of time and of changes in preferences and beliefs. Section VI concludes.

\section{TV Viewing}

Leisure activity today is dominated by television. The reduction in (paid and unpaid) working hours achieved over the past decades, resulting in more leisure time, has to a large extent been replaced by watching television. According to time use studies (Robinson and Godbey 1999: 338-347, see also Bittman 1999, Gershuny 2000, Goodin et al. 2005; Aguiar and Hurst 2006), 
the average leisure time of adult Americans (19 - 64 years of age) over the period 1965 - 95 rose by 6.2 hours from 34.8 to 41 hours ${ }^{1}$. In the same period of time, TV viewing time rose by 6 hours. In 1995, the average American spent 16 hours a week, or 2 1/4 hours a day, in front of the TV.

Similar trends can be observed for other industrialized countries. ${ }^{2}$ Between the $60 \mathrm{~s}$ and $90 \mathrm{~s}$, leisure time in those countries (for adults aged 20 to 59) rose, on average and controlling for structural changes, by well over 6 hours to 36 hours per week (Bittman 1998) ${ }^{3}$. At the end of the 90s, according to time use studies, TV viewing time in European countries ${ }^{4}$ averaged between almost 2 to 2 3/4 hours a day, or between 14 to 19 hours per week (Aliga and Winqvist 2003). 20 percent of the respondents in the European Social Survey 2002/3 indicated that they watch TV for more than 3 hours per day.

Television rating agencies report even higher average viewing times than time use studies: on average, in 2004, Americans (age 16 and older) watched close to 5 hours, and Europeans (about age 15 and older) ${ }^{5}$ about 3 3/4 hours a day (IP Germany 2005). This is due to the fact that other age groups are represented (especially the retired devote more than average time to TV watching) and that the electronic measuring instruments (so-called people's meters) cannot distinguish between primary, secondary and tertiary activities. It is known that many people engage in multi-tasking, for instance watching TV at the same time as cooking. But exclusive TV viewing is still a major activity taking up almost $70 \%$ of total TV time (Robinson and Godbey 1999; Grahn et al. 2003).

\section{Basic Hypothesis: Watching too much TV}

Two opposite views are possible when qualifying the huge amount of leisure time spent in front of the TV. At first glance, it might seem obvious that watching TV produces high

\footnotetext{
${ }^{1}$ Schor (1991) shows that the number of working hours in America has risen, and the amount of leisure time has fallen. But the data supporting this view has been criticized by authors using more accurate diary-based time use data, e.g., Robinson and Godbey (1999: 49-53), Kubey and Czikszentmihalyi (1990: 22), Sullivan and Gershuny (2001).

2 Denmark, The Netherlands, Finland, Italy, Belgium, Sweden, Germany (East and West), Czechoslovakia, Great Britain, Norway, Poland, France, Yugoslavia, Bulgaria, Hungary, Canada, USA and Australia.

${ }^{3}$ Gershuny (2000), for the same time period, shows an overall increase in leisure time without controlling for shifts in structural variables. The countries investigated are Canada, Denmark, The Netherlands, Norway, UK, USA, Hungary, and Finland.

${ }^{4}$ Denmark, Finland, Belgium, Sweden, Great Britain, Norway, France, Hungary, Estonia, Slovenia.

${ }^{5}$ Age categories vary by country.
} 
individual utility. TV watching is a voluntary activity and people can freely decide how much time they want to devote to it. However, an alternative view does not take consumer sovereignty as given but takes the possibility of a systematic error in TV consumption into account. In fact, studies suggest that TV viewing is only rated as below average or just as average enjoyment. American women, surprisingly enough, even rate it behind cleaning (Robinson and Godbey 1999: 250). Moreover, TV is identified as that activity which would be given up first if another activity would require more time (Robinson and Godbey 1999: 238-239).

We therefore want to study the second view: individuals tend to watch too much TV in the sense that they are afterwards sorry that they devoted so much time to viewing. Moreover, it seems difficult to overcome this weakness of will; many people are dissatisfied with their own past behavior, but nevertheless again and again devote more time to watching TV than, according to their own evaluation, is good for them. The basic hypothesis is thus that TV lends itself to over-consumption.

The main reason is that TV viewing is characterized by immediate benefits and negligible immediate marginal costs. One just has to push a button. In contrast to going to the cinema, the theater or any outdoor activity, there is no need to be appropriately dressed before leaving the house, there is no need to buy a ticket or to reserve a seat in advance. Watching TV does not require any special physical or cognitive abilities (Kubey and Csikszentmihalyi 1990: 173). Unlike other leisure activities, TV viewing does not need to be coordinated with other persons. It is quite possible to sit alone in front of the TV, while other leisure activities, such as tennis or golf, require a partner with similar time availability and similar preferences. As a consequence, watching TV has, compared to other leisure activities, an exceedingly low or nonexistent entry barrier. At the same time, it offers entertainment value and is considered to be one of the best ways of reducing stress. Moreover, while watching TV, immediate marginal costs are even lower and having a remote control is an invitation to ultra short-term optimization (zapping). Many of the costs resulting from such consumption behavior are not experienced immediately, or not predicted at all. The negative effects of not enough sleep, for example, only arise the next day, and the consequences of underinvestment in social contacts, education or career take much longer to appear. An increase in one's material aspirations might not be foreseen at all. These characteristics of the consumption good induce many individuals to fall prey to excessive TV viewing. Some studies discuss if television can 
become a habit (Christakis and Zimmerman 2006) or even an addiction in a medical or psychological sense (McIlwraith 1998; Kubey and Czikszentmihalyi 2002).

In economic theory, addiction is not necessarily considered to be irrational or suboptimal. In the model of rational addiction (Becker and Murphy 1988), addicts maximize their current and future utility under stable preferences. More recent work questions this rationality assumption in the case of addictive goods. Addictive behavior has, for example, successfully been modeled with time-inconsistent preferences (e.g. O'Donoghue and Rabin 1999a; Gruber and Koszegi 2001; O'Donoghue and Rabin 2002). In these models, individuals, due to their hyperbolic discounting, put more emphasis on the present as compared to all other periods of time and tend to grab immediate rewards. Gruber and Mullainathan (2005) test empirically if smokers have time inconsistent preferences and are therefore subject to self-control problems. They show that predicted smokers (i.e. people who would smoke with some probability given some tax level) would be happier if cigarette taxes were higher. This result is inconsistent with models of rational addiction in which higher prices reduce utility.

Time inconsistent preferences and self-control problems have been confirmed in many laboratory experiments (for an overview see e.g. Frederick et al. 2002), and they have been applied to other areas than addiction. ${ }^{6}$ Recent empirical evidence from the field is presented for saving decisions (Angeletos 2001), food consumption (Cutler et al. 2003; Shapiro 2005), job search (DellaVigna and Paserman 2005), labor supply (Fang and Silverman 2004) or health club visits (DellaVigna and Malmendier 2006).

Regarding television consumption, there is some (anecdotal) evidence that individuals may have self-control problems. $40 \%$ of US adults and $70 \%$ of US teenagers admit that they watch too much TV (Kubey and Czikszentmihalyi 2002). Another interesting observation is that short and long term evaluations of TV consumption tend to diverge - or, as Robinson and Godbey (1999: 299) put it: “ We may not enjoy television in general, but the programs we saw last night were pretty good.” Some individuals totally abstain from watching TV because they know that they would not otherwise be able to control their television viewing behavior. They cancel their subscription for cable TV in order not to "zap” too much, lock their TV set away in a cupboard or place an uncomfortable chair in front of it. Such self-control mechanisms are not necessary for time consistent individuals. To lower the utility, or raise the cost, of an undesired alternative would be irrelevant and unnecessary.

\footnotetext{
${ }^{6}$ For formal models of time inconsistent preferences, see e.g. Laibson (1997), O’Donoghue and Rabin (1999a; 1999b) and references mentioned therein.
} 
Here, the role of self-control problems and of mispredicting future costs and benefits in TV viewing is addressed with regard to consumers' utility. It is hypothesized that, for people facing similar restrictions, heavy TV viewing indicates impeded self-control rather than a taste for TV. Accordingly, heavy TV consumption is expected to result in lower utility. ${ }^{7}$

This hypothesis has, of course, to be understood ceteris paribus. Individual utility depends on a large number of other factors, which have to be taken into account in order to identify the specific effect of TV on utility. In the empirical analysis, utility is proxied by life satisfaction, and the effects are partial, controlling for major socio-demographic factors normally included in a happiness equation (see e.g. Frey and Stutzer 2002a; b).

\section{Data on TV Consumption and Life Satisfaction}

In order to empirically address the basic hypothesis on TV over-consumption, the first wave of the European Social Survey (ESS) is used. The ESS is a survey that was carried out in 22 European countries in 2002/2003. In each country, about 1'200 to 3’000 people were interviewed. For 338 observations, data for life satisfaction or television viewing is missing, resulting in a sample of 42 ’021 observations.

In addition to life satisfaction and television viewing time, the ESS includes a large number of socio-demographic characteristics. Control variables to be used are household income (adjusted for comparative price level at current US prices ${ }^{8}$ ), gender, age, marital status, employment status, education, working time, nationality and type of location.

The dependent variable life satisfaction is the response to the question: "All things considered, how satisfied are you with your life as a whole nowadays?” Answers are given on an 11-point scale ranging from 0 "extremely dissatisfied" to 10 "extremely satisfied” (figure 1). The average life satisfaction amounts to 7.0 (standard deviation 2.7). This average varies considerably between countries, and ranges from 5.6 in Hungary up to 8.4 in Denmark (figure 2). It is sometimes doubted that such life satisfaction data are comparable between nations, as the answers might partly reflect cultural differences. To control for such unobserved differences, country fixed effects are included in the regression analysis.

\footnotetext{
${ }^{7}$ See O’Donoghue and Rabin (1999b) for a discussion of the problem of welfare comparisons for people with time-inconsistent preferences.

${ }^{8}$ Data on comparative price levels are from the World Bank’s World Development Indicators.
} 
[Figures $1 \& 2$ about here]

Television consumption is also captured by one single question: “On an average weekday, how much time do you spend watching television?” Answers are given in 8 categories, ranging from "no time at all” to "more than three hours". About 3 percent of respondents don't watch any television at all, while over 20 percent spend more than 3 hours a day in front of their TV set (figure 3). This percentage varies considerably between countries. While only about 10 percent of respondents in Switzerland watch more than 3 hours TV a day, more than 38 percent do so in Greece (figure 4).

[Figures 3 \& 4 about here]

Subjective time use data is often criticized as being inaccurate or biased. "Watching television” might not be understood in the same way by all respondents, and they might not differentiate between television viewing as primary, secondary or even tertiary activity. Respondents might not even correctly remember all the times they were watching television, or they might revert to social norms or images they would like to have of themselves. Many also seem to translate the "average day" into "the average day that you watch television" (Robinson and Godbey 1999: 60). Nevertheless, answers to such questions seem to be a reliable measure for general television viewing behavior. A comparison of US data shows that different measurement methods give similar average results. In the 1992 SPPA National Survey with nearly 6,000 respondents (in which a single question, similar to the one in the European Social Survey, was asked about television viewing), the average television viewing time of 3 hours was close to time use data based on much more detailed diary surveys (Robinson and Godbey 1999: 152).

Based on the data described, a microeconomic happiness function is specified. The Life satisfaction $_{i}$ of individual i depends on his or her television consumption $T V_{i}$ and on personal characteristics $X_{i}$, as well as on country specific effects $D_{l}$ in country l:

Life satisfaction $_{i}=\beta_{0}+\beta_{1} T V_{i}+\gamma_{1} X_{i}+\gamma_{2} D_{l}+\varepsilon_{i}$ 
As the extent of television consumption is captured in a categorical variable with an openended category for those spending a lot of time watching TV, TV consumption cannot be included as a continuous variable. Instead, we include dummy variables in the regression equation. Those who watch less than half an hour of television a day form the reference group. The 6 categories for people who watch more than half an hour of TV a day are combined into 3 categories.

\section{Basic Estimation Results}

\section{(a) Partial Correlation Between TV Viewing and Life Satisfaction}

Table 1 reports the partial correlation between TV consumption and reported life satisfaction. In the first specification, a ordinary least squares estimator is applied. In view of the categorical nature of the dependent variable, a second specification is added, estimating an ordered probit. The similarities in the relative size of the coefficients indicate that the least squares estimator delivers a satisfactory approximation of the partial correlation. As the least squares results are easier to interpret, they are discussed primarily.

[Table 1 about here]

People who watch less than half an hour of TV a day are more satisfied with their life, ceteris paribus, than people who choose any other level of TV consumption. For those watching TV for anything between half an hour and 2.5 hours, average reported life satisfaction is about 0.10 points lower than in the reference group of people watching for less than half an hour. The estimated effect is even larger for people watching for more than 2.5 hours a day. On average, they report a 0.18 points lower life satisfaction than people in the reference group. All the differences are statistically significantly different from zero, at least at the 95\% level. The general finding is thus consistent with the basic hypothesis that extensive TV watching makes people worse off, because it indicates over-consumption due to a self-control problem and misprediction of future costs.

The partial correlation between TV consumption and life satisfaction is estimated for the whole population and is thus representing an average effect of TV viewing across people. It is most likely that some groups of people suffer higher disutility from extensive TV 
consumption than others. In the next section, ex ante hypotheses (in contrast to ex post rationalization) are formulated about people who are expected to lose the most if they watch TV extensively.

The partial correlation cannot easily be explained as spurious, simply reflecting some specific individual characteristics of people who spend a lot of time in front of the TV. A large set of socio-demographic characteristics that are systematically related with reported life satisfaction and might as well be with TV consumption is taken into consideration. These characteristics include, e.g., respondents' age, sex, nationality, marital status, household income, level of education, and employment status. The correlation of these variables with reported life satisfaction is discussed in various literature surveys (see, e.g. Frey and Stutzer 2002b). Specifically for the ESS, the determinants of life satisfaction are discussed in Lelkes (2005).

Partial correlations of other factors with life satisfaction allow for the assessment of the size of the effect of TV consumption in relative terms. For example, the difference in life satisfaction between those watching more than 2.5 hours and those watching less than half an hour (0.18) is more than one third of the difference in life satisfaction between people who have never been married and are without a partner and married people (0.53). The difference is about the same as the one between people having upper secondary education and those who simply completed primary school or the first stage of basic education (0.19).

\section{(b) Integration into the Literature and Discussion}

The basic results supplement the existing studies looking at the utility of TV consumption. Two approaches can be distinguished. The first captures the short run or instant effects by measuring “Activity Enjoyment Ratings”. In the context of time use studies, individuals are asked to rate TV viewing compared to other leisure time activities. In the United States, in 1985, with a rating of 7.8 on a scale from 0 to 10, it proved to be valued somewhat higher than the average enjoyment of 7 derived from other activities. Nevertheless, it ranks lower than most other activities undertaken in leisure time (Robinson and Godbey 1999: 243). On the index of positive affect of 900 Texan women constructed by Kahneman and co-workers (2004), TV ranks with 4.2 (on a scale from 0 to 6) roughly in the middle of all activities. With 2.2 hours per day, it is one of the most time consuming activities of these women. With the Experience Sampling Method, participants are randomly asked how they feel at a particular moment in time, using a beeper or a hand-held computer. On the affect scale, composed of cheerfulness, friendliness, happiness, and sociability, TV viewing is located in the lower part 
of the scale and can hardly be distinguished from reading, working, hobbies and idling. Eating, social contacts, sports and sex, on the other hand, are clearly higher ranked. Nevertheless, individuals have little inclination to do anything else (Kubey and Csikszentmihalyi 1990). This short-run evaluation captures the momentary affect, but it is difficult to determine the utility individuals would have derived had they done something else. In a second approach, long-run aspects of the utility derived from TV consumption are captured. In a survey on the general satisfaction with TV undertaken in the United States in 1975, TV was given an average rating of 5.9 points on an enjoyment scale ranging from 0 to 10. It ranks considerably behind most other leisure time activities and below the average of 6.8 of all rated activities. In 1995, TV viewing with 4.8 points ranked even lower when compared to all other leisure time pursuits (Robinson and Godbey 1999: 243, 250). In these surveys, TV viewing is generally rated much lower than in surveys capturing instant utility hinting at possible time-inconsistent preferences. Yet, such surveys are faced with the problem that watching TV is associated with a low ("couch potato") image, and there is a general consensus that many programs are stupid. For that reason, the answers given may reflect what is taken to be socially desirable. It should be noted that surveys on general life satisfaction (as used in our study) are not affected by this bias.

Several studies relate TV viewing with global measures of subjective well-being and are thus closest to our design. In a study of roughly 3,000 Americans in 1979 (Morgan 1984), people watching a lot of TV considered their life to be more "lousy" on an index consisting of the aspects lonely, boring, depressing, unsatisfying, uneventful and unhappy, and less "great” on an index consisting of the aspects interesting, active, meaningful, fun, fulfilling, stimulating and exciting, compared with people watching less TV. In a random survey of 1,000 West Germans, there is also a negative correlation between the duration of TV viewing and general life satisfaction, controlling for size of household, education and age (Espe and Seiwert 1987). TV viewing has also been found to have a negative effect on life satisfaction due to reducing time spent in relational activities (Bruni and Stanca 2006b; for a broader argument see also Putnam 1995; Corneo 2005).

So far, the negative partial correlation between TV consumption and subjective well-being has been interpreted in terms of over-consumption leading to a lower utility level. However, the partial correlation could well be the result of reverse causation. It is quite plausible that unhappy people watch more TV than happy ones. In fact, Espe and Seiwert (1987) postulate a causal influence of dissatisfaction with life on TV consumption, but offer no corresponding 
evidence. Controlling for as many situational factors as possible in the regression equation can attenuate the problem. However, it cannot be resolved, neither with an extensive set of control variables in a multiple regression analysis nor with panel data. ${ }^{9}$ Ideally, one would need information about exogenous changes in the opportunities for TV consumption, e.g. due to satellite TV being shut down or due to TV being introduced in a new place because of technical innovation. We are not aware of any such event that could be connected to survey data on reported subjective well-being.

We propose a different approach for further analysis of the effect of TV consumption on subjective well-being and for shedding light on the issue of causality. First, additional hypotheses are formulated, exploiting the heterogeneity in the expected effect of TV overconsumption for different groups of people. Second, evidence is collected that extensive TV consumption is related to systematically different preferences and beliefs. This would support the view that there are long-term costs of TV consumption that are very difficult to foresee.

\section{The Role of Opportunity Costs of Time and Changes in Preferences and Beliefs}

This section presents two extensions of the basic analysis on the statistical relationship between TV viewing and life satisfaction: (a) Opportunity costs of time are taken into account to assess the reduction in well-being due to self-control problems. (b) A path analysis is conducted to get an idea of the different ways that TV consumption can affect life satisfaction.

\section{(a) Opportunity Costs of Time and the Effect of Watching TV}

So far, it has been assumed that self-control problems in TV consumption affect everybody alike. Additional tests of the hypothesis that self-control problems in TV consumption reduce people's utility are possible if different types of individuals can be identified who suffer to a different extent from over-consumption. We emphasize that in particular individuals with high opportunity costs of time can use time more profitably when not watching TV. This includes, for instance, the self-employed (e.g. craftsmen, lawyers, architects or artists) or

\footnotetext{
${ }^{9}$ Panel data allow for the control of unobserved time-invariant individual specific factors that affect reported subjective well-being, as well as the explanatory variable of interest. This is not helpful in our analysis, because the entire theory is based on some people suffering from an unobserved timeinvariant self-control problem.
} 
persons in high positions (e.g. managers, top bureaucrats or politicians), who can freely transfer time from leisure to work. For this group of individuals, the self-control problem of watching too much TV generates considerable costs. Their utility is lower due to their inability to fully control themselves. In contrast, individuals with low opportunity costs of time suffer little, if any, disutility when they fail to watch the amount of TV they would consider optimal for themselves. Accordingly, it is hypothesized that TV consumption significantly lowers the life satisfaction of individuals with high opportunity costs of time, while it has a smaller negative effect on the life satisfaction of individuals with low opportunity costs of time.

Opportunity costs of time cannot be measured directly in our data. Therefore we use different indicators to distinguish between individuals with high and low opportunity costs of time:

(i) People who can freely transfer time between work and leisure tend to have higher (monetary) opportunity costs of time compared to people with fixed working hours. Hence, respondents are assigned to the two groups according to the flexibility of their working hours. Answers to the question "[P]lease say how much the management at your work allows you to be flexible in your working hours?” are given on an 11-point scale ranging from 0 "I have no influence” to 10 "I have complete control”. Respondents who indicate a value between 0 and 5 constitute the group with low opportunity costs of time, while those who give an answer between 6 and 10 form the other group. Only individuals who are employed (at least part time) are included in these sub-samples.

(ii) As a second indicator, employment status and profession are used. Retirees and the unemployed tend to have lots of free time and therefore form the group with low opportunity costs of time. On the other hand, working people, especially those who are self-employed and those in high positions and professions (legislators, senior officials, managers and professionals according to ISCO-88 classification) are assigned to the group with high opportunity costs of time.

Table 2 reports summary statistics for the different groups, as well as for the whole population. The groups divided according to flexibility of working hours do not differ much in most socio-demographic characteristics. The group with high opportunity costs of time watches a bit less TV (e.g. 20\% of respondents watch more than 2.5 hours TV a day compared to $26 \%$ in the other group) and has a somewhat higher income, as well as a higher level of education. People in this group report, on average, half a point higher life satisfaction 
(7.51 compared to 6.94) than people in the other group. The groups divided according to employment status and profession differ more with regard to their socio-demographic characteristics. The group with high opportunity costs of time includes more young people and more males, who watch considerably less TV (e.g. only 19\% of respondents watch more than 2.5 hours TV a day compared to $49 \%$ in the other group) and has a much better education (see also table A.1 in the appendix).

[Table 2 about here]

Table 3 reports the results of linear regression estimates for the different groups according to the different criteria. In order not to overload the table, the regression coefficients for the control variables are not explicitly shown (they are presented in table A.2 in the appendix).

Columns 1 and 2 show the estimation results for sub-samples with high and low opportunity costs of time (according to flexibility of working hours). Individuals in the group with high opportunity costs of time, who watch more television than the reference group, report lower life satisfaction ceteris paribus. The effects are quite considerable. The subjective well-being of viewers who watch half an hour and more television a day is between 0.33 and 0.38 points lower than that of light viewers spending less than half an hour watching television a day. The effects are statistically significant at the 99\% level. The magnitude of the coefficients corresponds to almost two third of the difference in life satisfaction between people who are divorced and without a partner and married people (0.61), and amounts in the highest category to over one third of the effect of unemployment $(-1.11)$ (both estimates are taken from the full sample). In contrast, for people with low opportunity costs of time, the coefficients of all television viewing categories are smaller (between 0.04 and 0.14 ) and not statistically significant.

[Table 3 about here]

A similar picture emerges when comparing the self-employed, managers, senior officials, legislators and professionals with retirees and unemployed persons (columns 3 and 4 in table 3). Coefficients in the high opportunity costs of time sub-sample are considerable in size. The 
average life satisfaction of people watching more than 1.5 hours TV a day is between 0.23 and 0.39 points lower compared to people who watch less than half an hour a day. These effects are statistically significant at the $95 \%$ to $99 \%$ level. In contrast, for the group with low opportunity costs of time, no correlation between television consumption and reported life satisfaction is visible. The coefficients are not statistically significant and very small. The coefficient for watching 0.5 to 1.5 hours TV is not statistically significant in either group. ${ }^{10}$

Of course, the question still arises whether the negative correlation for people with high opportunity costs of time is a causal relationship and, if so, in which direction the causality goes. However, it is difficult to understand why dissatisfied people, who have high opportunity costs of time, resort to TV viewing, while dissatisfied people with low opportunity costs of time do not.

\section{(b) TV Viewing and Differences in Preferences and Beliefs}

When people make decisions about watching TV, they are expected (and assumed to be able) to assess and to adequately take into consideration for themselves the long-term costs of TV viewing. Recent research on the prediction of future utility challenges the assumption underlying the revealed behavior approach of human well-being (for a survey see Wilson and Gilbert 2003). People systematically underestimate that their preferences change due to processes of adaptation (Loewenstein et al. 2003). Moreover, misprediction of utility is asymmetric, whereby the positive affects of a high material standard of living are overestimated and the positive affects of activities with strong intrinsic attributes, like socializing, are underestimated (Frey and Stutzer 2004). These aspects of mispredicting utility are directly relevant for TV consumption choice. People are expected to watch too much TV if they underestimate the future costs of TV viewing, due to neglecting social contacts and rising material aspirations. We are aware that it is not possible to discriminate between limited self-control with perfect and with imperfect projection of future beliefs in the current empirical framework. However, we are convinced that it is important to take misprediction of utility into account when refining the analysis of TV consumption.

Previous research has looked at the differences in beliefs and preferences between heavy and light TV viewers, induced by the fact that life portrayed on TV differs systematically from real life. Television programs contain much more violence and chaotic relationships and show

\footnotetext{
${ }^{10}$ Qualitatively the same results are obtained for both groups if the samples are pooled and interaction terms with the proxy for cost of time are estimated.
} 
many more affluent people and more luxury than exist in real life (e.g. Lichter et al. 1994). People who spend a lot of time watching TV therefore tend to overestimate crime rates, to show more anxiety (Gerbner et al. 2002) and less trust in others (e.g. Gerbner et al. 1980; Signorielli et al. 1995). They overestimate the affluence of others (O'Guinn and Shrum 1997), report higher material aspirations (e.g. Richins 1987; Sirgy et al. 1998; Shrum et al. 2005; Bruni and Stanca 2006a) and rate their own relative income lower which is related to lower subjective well-being (Layard 2005).

We perform a path analysis to shed some light on the long-term consequences of TV consumption and how they correlate with subjective well-being. An analysis is made as to whether people who watch more TV report lower financial satisfaction (keeping household income constant) and tend to believe that it is important to be rich, whether they feel less safe or trust others less and whether they think that they participate less in social activities. Financial satisfaction is captured with the question "[...] how do you feel about your household's income nowadays?" Answers are given on a scale from 1 "living comfortably on present income" to 4 "very difficult on present income", which is reverted for the empirical analysis. Respondents indicate on a scale from 1 to 6 how important it is for them to be rich. They are asked how safe they feel walking in the local area after dark. Answers range from 1 "very safe" to 4 "very unsafe", and this scale is reverted again in order to let higher values reflect a better feeling of safety. As a proxy for trust serves the answers to the question “Generally speaking, would you say that most people can be trusted or you can't be too careful in dealing with people?” Answers range on an 11-point scale from 0 "you can't be too careful” to 10 "most people can be trusted". Finally, respondents are asked: "Compared to other people of your age, how often would you say that you take part in social activities?” Answers range from 1 "much less than most" to 5 "much more than most".

Table 4 presents the ordinary least square estimates ${ }^{11}$ of the partial correlations between TV viewing and the different measures capturing people's beliefs and preferences. In all five estimations, the coefficients for watching more than 2.5 hours TV show the expected signs and are statistically significant at the 95\% to 99\% level: Heavy TV viewers report lower satisfaction with their financial situation, place more importance on affluence, feel less safe, trust other people less and think that they are involved in less social activities than their peers.

\footnotetext{
${ }^{11}$ In view of the categorical nature of the dependent variables, ordered probit estimates would be more accurate. However, the results of such estimates differ very little from the OLS estimates. As the latter are easier to interpret, they are presented here. The ordered probit estimates can be obtained from the authors on request.
} 
The effects are sizeable and (in relation to the respective scale of the dependent variable) are the largest for 'importance of being rich' and 'feeling of safety'. For intermediate levels of TV consumption, there are also positive effects on the importance of being rich and negative effects on the feeling of safety (statistically significant at the $95 \%$ to $99 \%$ level). There is no statistically significant correlation between intermediate levels of TV consumption and financial satisfaction, trust and perceived relative frequency of social activities ${ }^{12}$.

[Table 4 about here]

In the next step, an analysis is made of whether those preferences and beliefs influenced by TV affect reported life satisfaction. Accordingly, the five variables are included in the life satisfaction-television equation. For simplicity, least squares estimates are presented, and the intervening variables are included cardinally. ${ }^{13}$ Column I presents the results without including any intervening variable (corresponding to the results in table 1). In column II, all five intervening variables are included in the regression. The partial correlations with life satisfaction of all of the variables have the expected signs and are statistically significant at the 99\% level. The coefficient for people watching more then 2.5 hours TV is halved and drops from -0.18 in the regression without any intervening variable in column I to -0.09 . The coefficients for TV viewing between 0.5 and 2.5 hours are also decreased. Including the intervening variables one by one into the regression equations (columns III to VII in table 5) shows that the indirect effect of TV consumption on life satisfaction is smallest for 'importance of being rich' and is of about the same size for the other four variables (looking at the differences in coefficients for more than 2.5 hours TV viewing). According to the Sobel's test ${ }^{14}$, differences in coefficients between regression with and without intervening variables are all statistically significant for the category of heavy TV consumption.

\footnotetext{
${ }^{12}$ Absolute frequency of social contacts does not depend statistically significantly on the extent of watching TV.

${ }^{13}$ The respective estimates, with the intervening variables included ordinally, do not differ qualitatively from the ones presented here. They can be obtained from the authors on request.

${ }^{14}$ The Sobel's test shows the statistical significance of the indirect path from an explanatory variable (TV consumption) over the intervening variable to the dependent variable (life satisfaction). For OLS, the multiplied coefficients of this path correspond to the difference in coefficients of the explanatory variable in the regressions with and without intervening variable (MacKinnon et al. 1995; MacKinnon et al. 2002).
} 
[Table 5 about here]

The results of the path analysis show that the negative relationship between TV consumption and life satisfaction can partially be explained by differences in beliefs and preferences of people watching more TV. This finding corroborates the hypothesis that there are long-term consequences - or negative internalities - of TV consumption. If these consequences are not completely foreseen, people overestimate the utility from TV consumption and end up at a lower utility level. We are aware that the path analysis does not exclude reverse causation. However, it supports a richer picture of psychological processes involved in people's demand for TV consumption that might help to understand any systematic errors in TV consumption choice.

\section{Concluding Remarks}

Hardly anybody would deny that watching TV provides pleasure, at least part of the time, and that TV programs create focal points for personal discussions. However, many people report that they would like to spend less time watching TV. Observed consumption behavior might thus be a weak indicator for individuals’ pleasure from TV viewing.

This paper addresses the issue that long hours of TV viewing may indicate imperfect selfcontrol, as well as misprediction of the long-term costs of TV consumption, reducing individuals' well-being. Specifically, people with significant opportunity costs of time are expected to regret the amount of their own TV viewing. These are primarily persons with flexible working hours, who can freely transfer time between leisure and work. People with low opportunity costs of time, such as retired or unemployed people, or individuals with fixed working hours, are expected to be little burdened by their weak willpower, and therefore experience no significant utility loss, even if they spend many hours in front of the TV. In our empirical analysis, we apply data on subjective well-being as a methodological tool to directly evaluate whether some behavior is positively or negatively related to individual well-being, ceteris paribus. We find that people who spend a lot of time watching TV report, on average, lower life satisfaction, ceteris paribus. This negative effect is much larger for people with high opportunity costs of time than for those with low opportunity costs of time.

In a path analysis, some light is shed on the long-term consequences of TV consumption. We find that heavy TV viewers report lower satisfaction with their financial situation, place more 
importance on affluence, feel less safe, trust others less and think that they are involved less in social activities than their peers. The effects themselves can explain about half of the negative correlation between TV consumption and life satisfaction. The observed correlations are strong and do not disappear once a large set of individual characteristics are controlled for. Moreover, there is systematic structure in the data suggesting that in a major human activity in modern life individuals have systematically imperfect foresight and control over their own behavior. The utility gained is lower than what could be achieved. This shortcoming in human decision-making is reflected in efforts to reduce this utility loss. Time-constrained individuals resort to all kinds of rules designed to restrict their TV viewing. For instance, they make it a rule to only watch the news, place uncomfortable chairs in front of the TV set, locate the TV set in an unattractive room, or even decide not to have a TV set at all. Despite their efforts, our empirical results suggest that some of the individuals in question are unable to fully compensate for their self-control problem. 


\section{References}

Aguiar, Mark and Erik Hurst (2006). Measuring Trends in Leisure: The Allocation of Time over Five Decades. NBER Working Papers No. 12082, Cambride, MA: National Bureau of Economic Research.

Aliga, Christel and Karin Winqvist (2003). How Women and Men Spend Their Time. Results from 13 European Countries. Statistics in Focus Theme 3 - 12/2003, Eurostat.

Angeletos, George-Marios (2001). The Hyberbolic Consumption Model: Calibration, Simulation, and Empirical Evaluation. Journal of Economic Perspectives 15(3): 4768.

Becker, Gary S. and Kevin M. Murphy (1988). A Theory of Rational Addiction. Journal of Political Economy 96(4): 675-700.

Bittman, Michael (1998). The Land of the Lost Long Weekend? Trends in Free Time among Working Age Australians, 1974-1992. Society and Leisure 21(2): 353-378.

Bruni, Luigino and Luca Stanca (2006a). Income Aspirations, Television and Happiness: Evidence from the World Values Survey. Kyklos 59(2): 209-225.

Bruni, Luigino and Luca Stanca (2006b). Watching Alone: Relational Goods, Television and Happiness. Journal of Economic Behavior \& Organization, forthcoming.

Christakis, Dimitri A. and Frederick J. Zimmerman (2006). Early Television Viewing Is Associated with Protesting Turning Off the Television at Age 6. Medscape General Medicine 8(2): 63.

Corneo, Giacomo (2005). Work and Television. European Journal of Political Economy 21(1): 99-113.

Cutler, David M., Edward L. Glaeser and Jesse M. Shapiro (2003). Why Have Americans Become More Obese? Journal of Economic Perspectives 17(3): 93-118.

DellaVigna, Stefano and Ulrike Malmendier (2006). Paying Not to Go to the Gym. American Economic Review, forthcoming.

DellaVigna, Stefano and M. Daniele Paserman (2005). Job Search and Impatience. Journal of Labor Economics 23(3): 527-588.

Easterlin, Richard A. (2001). Income and Happiness: Towards an Unified Theory. Economic Journal 111(473): 465-484.

Espe, Hartmut and Margarete Seiwert (1987). Television Viewing Types, General Life Satisfaction, and Viewing Amount: An Empirical Study in West-Germany. European Journal of Communication 13: 95-110. 
Fang, Hanming and Dan Silverman (2004). Time-Inconsistency and Welfare Program Participation: Evidence from the NLSY. Cowles Foundation Discussion Paper No. 1465, Cowles Foundation for Research in Economics at Yale University.

Frederick, Shane, George Loewenstein and Ted O'Donoghue (2002). Time Discounting and Time Preference: A Critical Review. Journal of Economic Literature 40(2): 351-401.

Frey, Bruno S. and Alois Stutzer (2002a). Happiness and Economics: How the Economy and Institutions Affect Well-Being. Princeton, NJ: Princeton University Press.

Frey, Bruno S. and Alois Stutzer (2002b). What Can Economists Learn from Happiness Research? Journal of Economic Literature 40(2): 402-35.

Frey, Bruno S. and Alois Stutzer (2004). Economic Consequences of Mispredicting Utility. IEW Working Paper No. 218, University of Zurich.

Gerbner, George, Larry Gross, Michael Morgan and Nancy Signorielli (1980). The Mainstreaming of America: Violence Profile No 11. Journal of Communication 30(3): 10-29.

Gerbner, George, Larry Gross, Michael Morgan, Nancy Signorielli and James Shanahan (2002). Growing up with Television: Cultivation Processes. In: Jennings Bryant and Dolf Zillmann (eds). Media Effects. Advances in Theory and Research. Mahwah, NJ: Lawrence Erlbaum Associates: 43-67.

Gershuny, Jonathan (2000). Changing Times: Work and Leisure in Postindustrial Society. Oxford: Oxford University Press.

Goodin, Robert E., James Mahmud Rice, Michael Bittman and Peter Saunders (2005). The Time Pressure Illusion: Discretionary Time Versus Free Time. Social Indicators Research 73(1): 43-70.

Grahn, Almut, Andreas Lehmann, Edgar Schmitz and Carsten Breinker (2003). MIT - Medien im Tagesablauf 2003. Cologne, Germany: IP Germany.

Gruber, Jonathan and Botond Koszegi (2001). Is Addiction "Rational"? Theory and Evidence. Quarterly Journal of Economics 116(4): 1261-1303.

Gruber, Jonathan and Sendhil Mullainathan (2005). Do Cigarette Taxes Make Smokers Happier? B.E. Journals in Economic Analysis and Policy: Advances in Economic Analysis and Policy 5(1): 1-43.

IP Germany (ed.) (2005). Television 2005: International Keyfacts. Kologne, Germany: IP Germany. 
Kahneman, Daniel, Alan B. Krueger, David A. Schkade, Norbert Schwarz and Arthur A. Stone (2004). A Survey Method for Characterizing Daily Life Experience: The Day Reconstruction Method. Science 306(5702): 1776-1780.

Kubey, Robert and Mihaly Csikszentmihalyi (1990). Television and the Quality of Life. How Viewing Shapes Everyday Experience. Hillsdale, NJ: Lawrence Erlbaum Associates.

Kubey, Robert and Mihaly Czikszentmihalyi (2002). Television Addiction Is No Mere Metaphor. Scientific American 286(2): 74-80.

Laibson, David (1997). Golden Eggs and Hyperbolic Discounting. Quarterly Journal of Economics 112(2): 443-477.

Layard, Richard (2005). Happiness: Lessons from a New Science. New York, NY: Penguin.

Lelkes, Orsolya (2005). Knowing What Is Good for You. Empirical Analysis of Personal Preferences and the 'Objective Good'. Journal of Socio-Economics, forthcoming.

Lichter, S. Robert, Linda S. Lichter and Stanley Rothman (1994). Prime Time: How TV Portrays American Culture. Washington, DC: Regnery.

Loewenstein, George, Ted O'Donoghue and Matthew Rabin (2003). Projection Bias in Predicting Future Utility. Quarterly Journal of Economics 118(4): 1209-1248.

Loewenstein, George and David A. Schkade (1999). Wouldn't It Be Nice? Predicting Future Feelings. In: Daniel Kahneman, Ed Diener and Norbert Schwarz (eds). Well-Being: The Foundation of Hedonic Psychology. New York, NY: Russell Sage Foundation: 85-105.

MacKinnon, David P., Chondra M. Lockwood, Jeanne M. Hoffman, Stephen G. West and Virgil Sheets (2002). A Comparison of Methods to Test Mediation and Other Intervening Variable Effects. Psychological Methods 7(1): 83-104.

MacKinnon, David P., Ghulam Warsi and James H. Dwyer (1995). A Simulation Study of Mediated Effect Measures. Multivariate Behavioral Research 30(1): 41-62.

McIlwraith, Robert D. (1998). "I'm Addicted to Television": The Personality, Imagination, and TV Watching Patterns of Self-Identified TV Addicts. Journal of Broadcasting \& Electronic Media 42(3): 371-386.

Morgan, Michael (1984). Heavy Television Viewing and Perceived Quality of Life. Journalism Quarterly 61(3): 499-504.

O'Donoghue, Ted and Matthew Rabin (1999a). Addiction and Self Control. In: Jon Elster (ed.). Addiction: Entries and Exits. New York, NY: Russell Sage Foundation: 169206. 
O'Donoghue, Ted and Matthew Rabin (1999b). Doing It Now or Later. American Economic Review 89(1): 103-124.

O'Donoghue, Ted and Matthew Rabin (2002). Addiction and Present-Biased Preferences. Working Paper E02-312, Economics Department, University of California, Berkeley.

O'Guinn, Thomas C. and L. J. Shrum (1997). The Role of Television in the Construction of Consumer Reality. Journal of Consumer Research 23(4): 278-294.

Putnam, Robert D. (1995). Tuning in, Tuning out - the Strange Disappearance of Social Capital in America. Political Science \& Politics 28(4): 664-683.

Richins, Marsha L. (1987). Media, Materialism, and Human Happiness. Advances in Consumer Research 14: 352-356.

Robinson, John P. and Geoffrey Godbey (1999). Time for Life: The Surprising Ways Americans Use Their Time. 2nd ed. University Park, PA: Pennsylvania State University Press.

Schelling, Thomas C. (1984). Self-Command in Practice, in Policy, and in a Theory of Rational Choice. American Economic Review 74(2): 1-11.

Schor, Juliet B. (1991). The Overworked American: The Unexpected Decline of Leisure. New York, NY: Basic Books.

Sen, Amartya (1982). Choice, Welfare and Measurement. Oxford, UK: Blackwell.

Sen, Amartya (1995). Rationality and Social Choice. American Economic Review 85(1): 1-24.

Shapiro, Jesse M. (2005). Is There a Daily Discount Rate? Evidence from the Food Stamp Nutrition Cycle. Journal of Public Economics, forthcoming.

Shrum, L. J., James E. Burroughs and Aric Rindfleisch (2005). Television's Cultivation of Material Values. Journal of Consumer Research 32(473-479).

Signorielli, Nancy, George Gerbner and Michael Morgan (1995). Violence on Television - the Cultural Indicators Project. Journal of Broadcasting \& Electronic Media 39(2): 278283.

Sirgy, M. Joseph, Dong-Jin Lee, Rustan Kosenko, H. Lee Meadow, Don Rahtz, Muris Cicic, Guang Xi Jin, Duygun Yarsuvat, David L. Blenkhorn and Newell Wright (1998). Does Television Viewership Play a Role in the Perception of Quality of Life? Journal of Advertising 27(1): 125-142.

Sullivan, O. and J. Gershuny (2001). Cross-National Changes in Time-Use: Some Sociological (Hi)Stories Re-Examined. British Journal of Sociology 52(2): 331-347.

Thaler, Richard H. (1992). The Winner's Curse. Paradoxes and Anomalies of Economic Life. New York, NY: Free Press. 
Wilson, Timothy D. and Daniel T. Gilbert (2003). Affective Forecasting. In: M. Zanna (ed.). Advances in Experimental Social Psychology, vol. 35. New York: Elsevier: 345-411. 
Figure 1: Reported Life Satisfaction in 22 European Countries 2002/2003

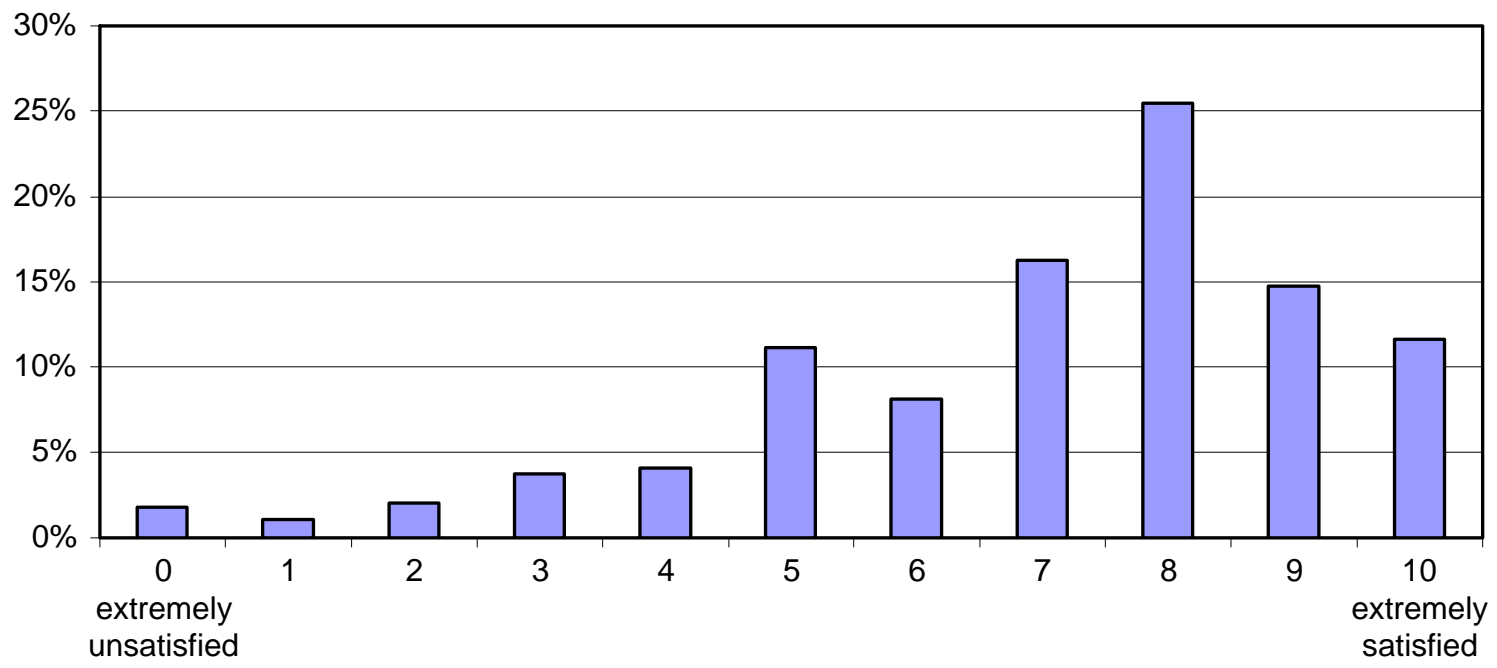

Data source: European Social Survey.

Figure 2: Average Reported Life Satisfaction in 22 European Countries 2002/2003

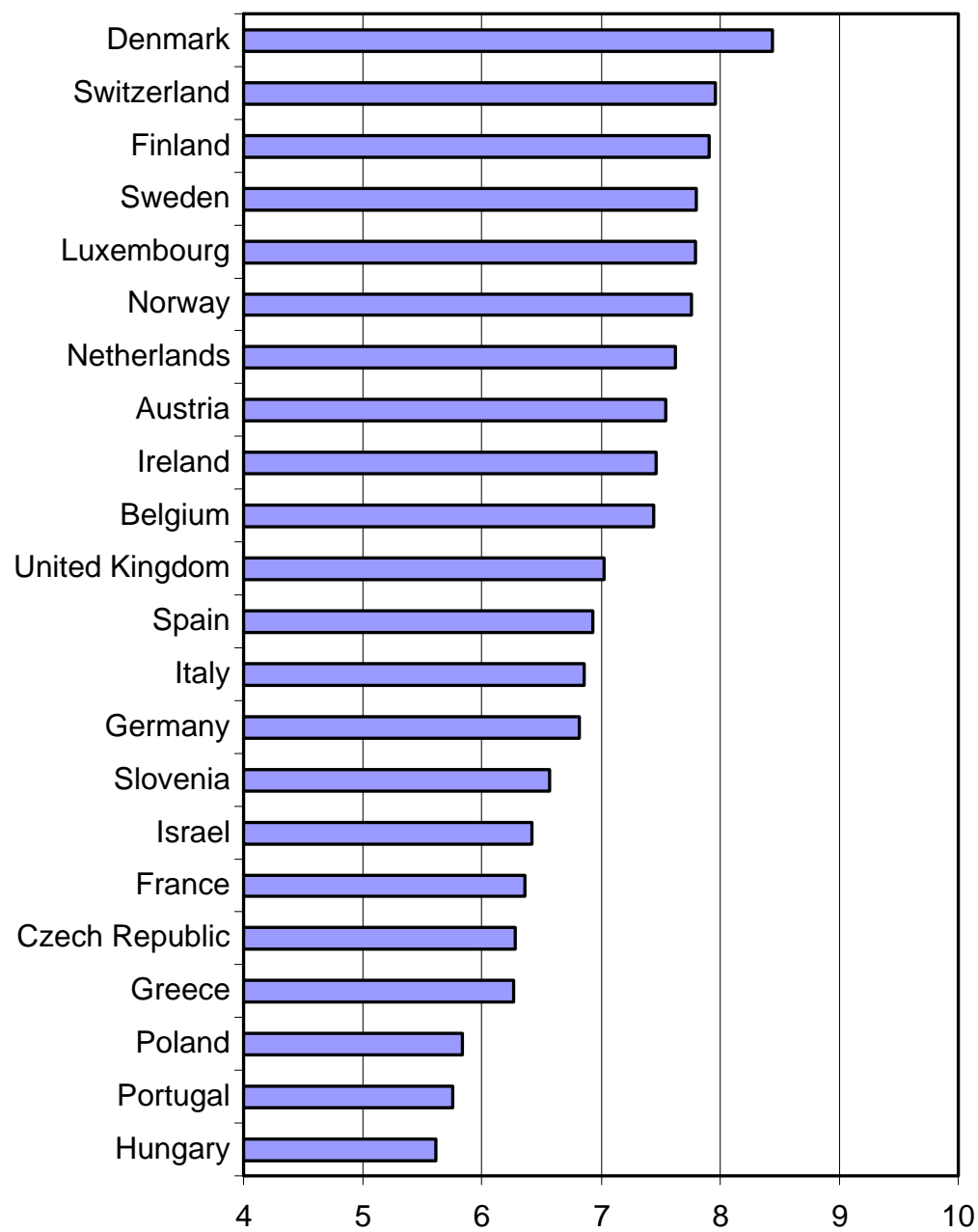

Note: Average reported life satisfaction on a scale from 0 "extremely unsatisfied" to 10 "extremely satisfied".

Data source: European Social Survey. 
Figure 3: Reported Television Consumption in 22 European Countries 2002/2003

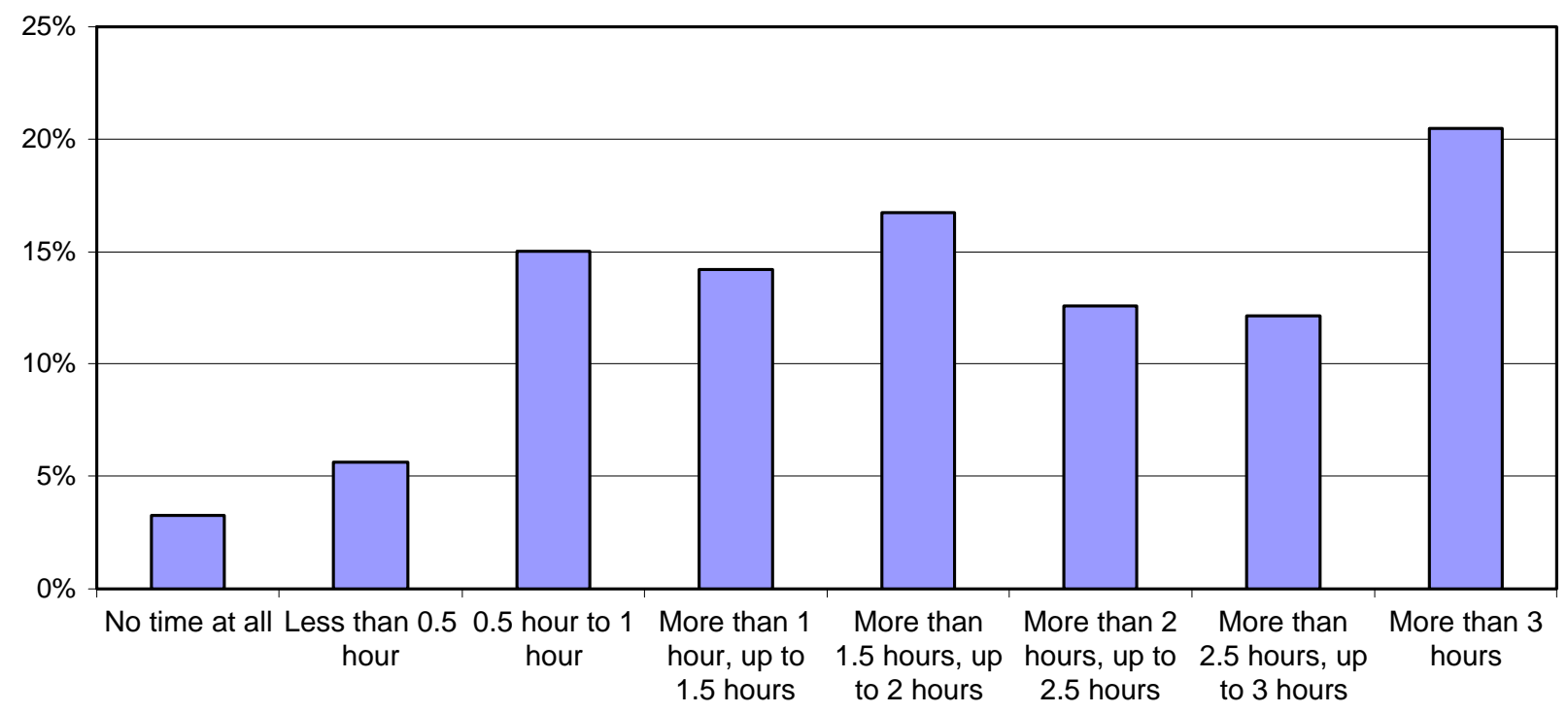

Data source: European Social Survey.

Figure 4: Heavy Television Viewers in 22 European Countries 2002/2003

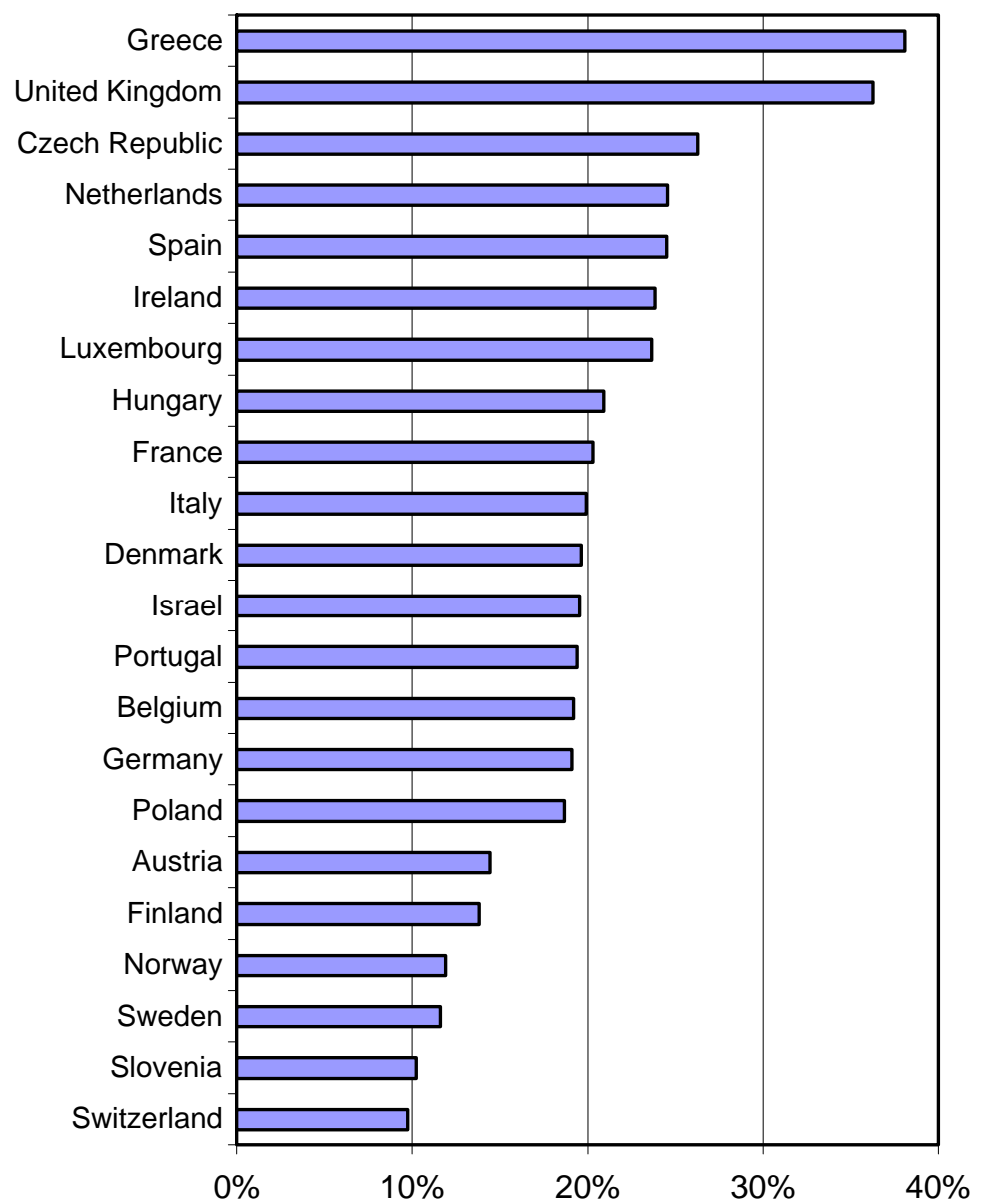

Note: Fraction of respondents with more than 3 hours reported TV viewing on an average weekday. Data source: European Social Survey. 
Table 1: Television Consumption and Life Satisfaction

\begin{tabular}{|c|c|c|c|c|}
\hline \multirow{2}{*}{$\begin{array}{l}\text { Dependent variable: } \\
\text { Life satisfaction }\end{array}$} & \multicolumn{2}{|l|}{ OLS } & \multicolumn{2}{|c|}{ Orderd probit } \\
\hline & Coefficient & t-value & Coefficient & t-value \\
\hline No TV at all & -0.110 & -1.56 & -0.013 & -0.36 \\
\hline Less than 0.5 hour TV & \multicolumn{4}{|c|}{ Reference group } \\
\hline 0.5 to 1.5 hours TV & $-0.101 *$ & -2.18 & $-0.058 *$ & -2.49 \\
\hline More than 1.5 to 2.5 hours TV & $-0.101 *$ & -2.14 & $-0.067 * *$ & -2.86 \\
\hline More than 2.5 hours TV & $-0.183 * *$ & -3.84 & $-0.091 * *$ & -3.82 \\
\hline Working hours & 0.005 & 1.43 & 0.001 & 0.86 \\
\hline Working hours, squared & $-0.00008 *$ & -2.33 & $-0.00003(*)$ & -1.70 \\
\hline ln (household income, PPP) & $0.362 * *$ & 21.36 & $0.160 * *$ & 18.89 \\
\hline Age & $-0.068 * *$ & -16.72 & $-0.033 * *$ & -16.37 \\
\hline Age, squared & $0.0007 * *$ & 16.99 & $0.0003 * *$ & 16.76 \\
\hline Male & \multicolumn{4}{|c|}{ Reference group } \\
\hline Female & $0.136 * *$ & 6.16 & $0.081 * *$ & 7.36 \\
\hline Foreigner & \multicolumn{4}{|c|}{ Reference group } \\
\hline Citizen of country & $0.332 * *$ & 6.04 & $0.158 * *$ & 5.74 \\
\hline Married, living with partner & \multicolumn{4}{|c|}{ Reference group } \\
\hline Married, not living with partner & $-0.914 * *$ & -5.64 & $-0.409 * *$ & -5.08 \\
\hline Separated, living with partner & $-0.407 *$ & -2.09 & $-0.212 *$ & -2.20 \\
\hline Separated, not living with partner & $-0.950 * *$ & -10.17 & $-0.466 * *$ & -10.06 \\
\hline Divorced, living with partner & $-0.337 * *$ & -4.07 & $-0.180 * *$ & -4.37 \\
\hline Divorced, not living with partner & $-0.605 * *$ & -12.15 & $-0.291 * *$ & -11.77 \\
\hline Widowed, living with partner & $-0.363 *$ & -2.32 & $-0.172 *$ & -2.20 \\
\hline Widowed, not living with partner & $-0.539 * *$ & -11.98 & $-0.264 * *$ & -11.80 \\
\hline $\begin{array}{l}\text { Never been married, living with } \\
\text { partner }\end{array}$ & $-0.262 * *$ & -5.48 & $-0.135 * *$ & -5.64 \\
\hline $\begin{array}{l}\text { Never been married, not living with } \\
\text { partner }\end{array}$ & $-0.528 * *$ & -13.99 & $-0.275 * *$ & -14.61 \\
\hline No children at home & \multicolumn{4}{|c|}{ Reference group } \\
\hline Children living at home & $-0.200 * *$ & -6.44 & $-0.103 * *$ & -6.65 \\
\hline Not completed primary education & $-0.479 * *$ & -8.06 & $-0.223 * *$ & -7.57 \\
\hline $\begin{array}{l}\text { Primary or first stage of basic } \\
\text { education }\end{array}$ & \multicolumn{4}{|c|}{ Reference group } \\
\hline $\begin{array}{l}\text { Lower secondary or second stage of } \\
\text { basic education }\end{array}$ & $0.097 * *$ & 2.59 & $0.045 *$ & 2.44 \\
\hline Upper secondary education & $0.191 * *$ & 5.13 & $0.075 * *$ & 4.01 \\
\hline $\begin{array}{l}\text { Post secondary, non-tertiary } \\
\text { education }\end{array}$ & $0.333 * *$ & 6.73 & $0.130 * *$ & 5.27 \\
\hline First stage of tertiary education & $0.325 * *$ & 7.32 & $0.126 * *$ & 5.70 \\
\hline Second stage of tertiary education & $0.400 * *$ & 7.27 & $0.141 * *$ & 5.16 \\
\hline Paid work, employed & \multicolumn{4}{|c|}{ Reference group } \\
\hline Paid work, self-employed & 0.034 & 0.80 & 0.023 & 1.10 \\
\hline Unemployed, looking for a job & $-1.112 * *$ & -11.19 & $-0.485 * *$ & -9.82 \\
\hline
\end{tabular}


Continuation of table 1

\begin{tabular}{lcccc}
\hline Unemployed, not looking for a job & $-0.658 * *$ & -5.68 & $-0.292 * *$ & -5.07 \\
Education & $0.341 * *$ & 3.73 & $0.140 * *$ & 3.08 \\
Permanently sick or disabled & $-1.066 * *$ & -9.99 & $-0.478 * *$ & -9.02 \\
Retired & 0.024 & 0.28 & 0.013 & 0.30 \\
Community or military service & $0.344\left(^{*}\right)$ & 1.75 & $0.164(*)$ & 1.67 \\
Housework, looking after children & -0.014 & -0.17 & 0.002 & 0.04 \\
Big city & \multicolumn{5}{c}{ Reference group } \\
Suburbs & -0.020 & -0.56 & -0.002 & -0.11 \\
Town, small city & 0.037 & 1.20 & 0.025 & 1.64 \\
Country village & $0.151 * *$ & 4.85 & $0.080 * *$ & 5.16 \\
Farm, home in countryside & $0.232 * *$ & 4.62 & $0.128 * *$ & 5.09 \\
\hline Country-fixed effects & \multicolumn{4}{c}{ Yes } \\
\hline Constant & $5.854 * *$ & 28.42 \\
\hline Observations & 42,021 \\
$\mathrm{R}^{2} /$ Pseudo ${ }^{2}$ & 0.18 \\
\hline
\end{tabular}

Notes:

(1) ** significant on 99\% level, * significant on 95\% level, (*) significant on $90 \%$ level.

(2) Variable for household size and dummy variables for highest income category and for the different countries are not shown. Dummy variables for missing observations for income, household size, working hours, gender, marital status, children, education, employment status, and citizenship are neither shown.

Data Source: European Social Survey, World Development Indicators 
Table 2: Summary Statistics

Mean values
Flexibility of working hours as distinction criteria
Employment status / profession as distinction criteria

Group with Group with Group with Group with

$\begin{array}{ccccc}\text { Whole } & \text { high } & \text { low } & \text { high } & \text { low } \\ \text { population } & \text { opportunity } & \text { opportunity } & \text { opportunity } & \text { opportunity }\end{array}$ costs of time costs of time costs of time costs of time

\begin{tabular}{|c|c|c|c|c|c|}
\hline Life satisfaction & 7.03 & 7.51 & 6.94 & 7.28 & 6.73 \\
\hline No TV at all & $3.25 \%$ & $3.00 \%$ & $2.79 \%$ & $3.73 \%$ & $2.72 \%$ \\
\hline Less than 0.5 hour TV & $5.61 \%$ & $6.86 \%$ & $6.20 \%$ & $8.66 \%$ & $2.82 \%$ \\
\hline 0.5 to 1.5 hours TV & $29.21 \%$ & $38.59 \%$ & $32.98 \%$ & $40.71 \%$ & $18.35 \%$ \\
\hline More than 1.5 to 2.5 hours TV & $29.34 \%$ & $31.47 \%$ & $32.44 \%$ & $27.90 \%$ & $26.95 \%$ \\
\hline More than 2.5 hours TV & $32.59 \%$ & $20.08 \%$ & $25.59 \%$ & $19.01 \%$ & $49.15 \%$ \\
\hline Working hours & 18.87 & 39.20 & 38.35 & 41.03 & 0 \\
\hline Household income (EUR, PPP) & 1956.56 & 2919.68 & 2065.86 & 2879.43 & 1313.70 \\
\hline Age & 46.18 & 40.96 & 39.44 & 43.50 & 64.32 \\
\hline $\begin{array}{l}\text { Not completed primary } \\
\text { education }\end{array}$ & $3.91 \%$ & $0.43 \%$ & $1.19 \%$ & $1.09 \%$ & $8.76 \%$ \\
\hline $\begin{array}{l}\text { Primary or first stage of basic } \\
\text { education }\end{array}$ & $13.27 \%$ & $4.66 \%$ & $8.09 \%$ & $7.08 \%$ & $22.44 \%$ \\
\hline $\begin{array}{l}\text { Lower secondary or second } \\
\text { stage of basic education }\end{array}$ & $22.68 \%$ & $15.96 \%$ & $22.34 \%$ & $12.50 \%$ & $24.86 \%$ \\
\hline Upper secondary education & $32.48 \%$ & $35.45 \%$ & $37.75 \%$ & $24.29 \%$ & $27.03 \%$ \\
\hline $\begin{array}{l}\text { Post secondary, non-tertiary } \\
\text { education }\end{array}$ & $8.30 \%$ & $10.88 \%$ & $10.24 \%$ & $9.53 \%$ & $5.14 \%$ \\
\hline First stage of tertiary education & $12.92 \%$ & $21.30 \%$ & $13.21 \%$ & $28.92 \%$ & $8.08 \%$ \\
\hline $\begin{array}{l}\text { Second stage of tertiary } \\
\text { education }\end{array}$ & $5.72 \%$ & $11.01 \%$ & $6.68 \%$ & $16.22 \%$ & $3.26 \%$ \\
\hline Observations & 42,021 & 6,460 & 7,062 & 5,950 & 8,974 \\
\hline
\end{tabular}

Data source: European Social Survey, World Development Indicators. 
Table 3: Television Consumption and Life Satisfaction: Opportunity Costs of Time

\begin{tabular}{lcccc}
\hline $\begin{array}{l}\text { Dependent variable: } \\
\text { Life satisfaction }\end{array}$ & $\begin{array}{c}\text { Flexibility of working hours as } \\
\text { distinction criteria } \\
\text { Group with high } \\
\text { opportunity costs } \\
\text { of time }\end{array}$ & $\begin{array}{c}\text { Group with low } \\
\text { opportunity costs } \\
\text { of time }\end{array}$ & $\begin{array}{c}\text { Employment status / profession as } \\
\text { distinction criteria }\end{array}$ \\
$\begin{array}{l}\text { Group with high } \\
\text { opportunity costs } \\
\text { of time }\end{array}$ & $\begin{array}{c}\text { Group with low } \\
\text { opportunity costs } \\
\text { of time }\end{array}$ \\
\hline No TV at all & $-0.355^{*}$ & 0.056 & -0.238 & -0.251 \\
Less than 0.5 hours TV & $(-2.33)$ & $(0.33)$ & $(-1.58)$ & $(-1.24)$ \\
0.5 to 1.5 hours TV & $-0.328 * *$ & -0.072 & -0.074 & -0.105 \\
More than 1.5 to 2.5 & $(-3.59)$ & $(-0.69)$ & $(-0.80)$ & $(-0.70)$ \\
hours TV & $-0.339 * *$ & -0.041 & $-0.229 *$ & 0.052 \\
More than 2.5 hours TV & $(-3.62)$ & $(-0.38)$ & $(-2.38)$ & $(0.35)$ \\
& $-0.377 * *$ & -0.140 & $-0.389 * *$ & -0.012 \\
\hline Socio-demographic & $(-3.78)$ & $(-1.28)$ & $(-3.76)$ & $(-0.08)$ \\
characteristics & Yes & Yes & Yes & Yes \\
Country-fixed effects & Yes & Yes & Yes & Yes \\
\hline Constant & $6.203 * *$ & $5.410 * *$ & $6.204 * *$ & $6.919 * *$ \\
\hline Observations & $(12.39)$ & $(10.45)$ & $(10.94)$ & $(11.93)$ \\
\hline $\mathrm{R}^{2}$ & 6,460 & 7,062 & 5,950 & 8,974 \\
\hline
\end{tabular}

Notes:

(1) Group 1 contains respondents with flexibility of working hours of 6 and higher on a scale from 0 to 10 and group 2 contains respondents with flexibility of working hours of 5 and lower. In both groups, respondents' employment status is "paid work, employed" and nothing else. Group 3 contains the self-employed, as well as managers, senior officials, legislators, professionals (according to ISCO-88 classification) with employment status "paid work" (employed or self-employed) and nothing else, and group 4 contains retirees and the unemployed with no other employment status.

(2) Ordinary least squares estimations.

(3) ** significant at 99\% level, * significant at 95\% level, (*) significant at $90 \%$ level.

(4) t-values in brackets.

(5) Variables for working hours, household income, age, gender, citizenship, marital status, children, education, employment status, area of living and household size, and dummy variables for highest income category and for the different countries are not shown. Dummy variables for missing observations for income, household size, working hours, gender, marital status, children, education, employment status, and citizenship are neither shown. Data Source: European Social Survey, World Development Indicators. 
Table 4: Television Consumption and People’s Beliefs and Preferences

\begin{tabular}{|c|c|c|c|c|c|}
\hline Dependent variable: & $\begin{array}{c}\text { (I) } \\
\text { Financial } \\
\text { satisfaction }\end{array}$ & $\begin{array}{c}\text { (II) } \\
\text { Importance to } \\
\text { be rich }\end{array}$ & $\begin{array}{l}\text { (III) } \\
\text { Feeling of } \\
\text { safety }\end{array}$ & $\begin{array}{l}\text { (IV) } \\
\text { Trust in } \\
\text { people }\end{array}$ & $\begin{array}{c}(\mathrm{V}) \\
\text { Perceived } \\
\text { social activities }\end{array}$ \\
\hline No TV at all & $\begin{array}{l}-0.050 * \\
(-2.18)\end{array}$ & $\begin{array}{r}0.022 \\
(0.48)\end{array}$ & $\begin{array}{r}0.012 \\
(0.46)\end{array}$ & $\begin{array}{l}-0.081 \\
(-1.03)\end{array}$ & $\begin{array}{l}-0.145 * * \\
(-4.58)\end{array}$ \\
\hline Less than 0.5 hour TV & \multicolumn{5}{|c|}{ Reference group } \\
\hline 0.5 to 1.5 hours TV & $\begin{array}{r}0.005 \\
(0.34)\end{array}$ & $\begin{array}{l}0.092 * \\
(3.10)\end{array}$ & $\begin{array}{l}-0.060 * * \\
(-3.65)\end{array}$ & $\begin{array}{l}-0.040 \\
(-0.79)\end{array}$ & $\begin{array}{l}-0.016 \\
(-0.74)\end{array}$ \\
\hline $\begin{array}{l}\text { More than } 1.5 \text { to } 2.5 \\
\text { hours TV }\end{array}$ & $\begin{array}{r}0.004 \\
(0.27)\end{array}$ & $\begin{array}{l}0.163 * * \\
(5.44)\end{array}$ & $\begin{array}{l}-0.061 * * \\
(-3.69)\end{array}$ & $\begin{array}{r}-0.044 \\
(-0.84)\end{array}$ & $\begin{array}{l}-0.010 \\
(-0.49)\end{array}$ \\
\hline More than 2.5 hours TV & $\begin{array}{l}-0.037 * \\
(-2.35) \\
\end{array}$ & $\begin{array}{l}0.218 * * \\
(7.16)\end{array}$ & $\begin{array}{l}-0.092 * * \\
(-5.49)\end{array}$ & $\begin{array}{l}-0.164 * * \\
(-3.11)\end{array}$ & $\begin{array}{l}-0.106 * * \\
(-4.93) \\
\end{array}$ \\
\hline $\begin{array}{l}\text { Socio-demographic } \\
\text { characteristics }\end{array}$ & Yes & Yes & Yes & Yes & Yes \\
\hline Country-fixed effects & Yes & Yes & Yes & Yes & Yes \\
\hline Observations & 41,520 & 37,360 & 41,644 & 41,865 & 41,247 \\
\hline $\mathrm{R}^{2}$ & 0.36 & 0.12 & 0.20 & 0.17 & 0.07 \\
\hline
\end{tabular}

Notes:

(1) Dependent variables: Financial satisfaction on scale from 0 to 3, importance to be rich on scale from 0 to 5 , feeling of safety on scale from 0 to 3 , trust in people on scale from 0 to 10 , perceived relative frequency of social activities on scale from 0 to 4 .

(2) Ordinary least squares estimations.

(4) ** significant on 99\% level, * significant on 95\% level, (*) significant on 90\% level.

(5) t-values in brackets.

(6) Variables for working hours, household income, age, gender, citizenship, marital status, children, education, employment status, area of living and household size, and dummy variables for highest income category and for the different countries are not shown. Dummy variables for missing observations for income, household size, working hours, gender, marital status, children, education, employment status, and citizenship are neither shown. Data Source: European Social Survey, World Development Indicators. 
Table 5: Television Consumption and Life Satisfaction: Intermediate Processes

\begin{tabular}{|c|c|c|c|c|c|c|c|}
\hline $\begin{array}{l}\text { Dependent variable: } \\
\text { Life satisfaction }\end{array}$ & $\begin{array}{c}\text { (I) } \\
\text { excl. } \\
\text { channels }\end{array}$ & $\begin{array}{c}\text { (II) } \\
\text { incl. } \\
\text { all } \\
\text { channels }\end{array}$ & $\begin{array}{c}\text { (III) } \\
\text { incl. } \\
\text { financial } \\
\text { satisfaction }\end{array}$ & $\begin{array}{c}\text { (IV) } \\
\text { incl. } \\
\text { importance } \\
\text { to be rich }\end{array}$ & $\begin{array}{c}(\mathrm{V}) \\
\text { incl. feeling } \\
\text { of safety }\end{array}$ & $\begin{array}{l}\text { (VI) } \\
\text { incl. } \\
\text { trust in } \\
\text { people }\end{array}$ & $\begin{array}{c}\text { (VII) } \\
\text { incl. } \\
\text { social } \\
\text { activities }\end{array}$ \\
\hline No TV at all & $\begin{array}{l}-0.110 \\
(-1.56)\end{array}$ & $\begin{array}{l}-0.036 \\
(-0.53)\end{array}$ & $\begin{array}{l}-0.075 \\
(-1.10)\end{array}$ & $\begin{array}{l}-0.109 \\
(-1.56)\end{array}$ & $\begin{array}{l}-0.111 \\
(-1.59)\end{array}$ & $\begin{array}{l}-0.096 \\
(-1.38)\end{array}$ & $\begin{array}{l}-0.066 \\
(-0.95)\end{array}$ \\
\hline Less than 0.5 hour TV & \multicolumn{7}{|c|}{ Reference group } \\
\hline 0.5 to 1.5 hours TV & $\begin{array}{l}-0.101 * \\
(-2.18)\end{array}$ & $\begin{array}{l}-0.084\left(^{*}\right) \\
(-1.90)\end{array}$ & $\begin{array}{l}-0.106 * \\
(-2.36)\end{array}$ & $\begin{array}{l}-0.100 * \\
(-2.14)\end{array}$ & $\begin{array}{l}-0.084(*) \\
(-1.83)\end{array}$ & $\begin{array}{l}-0.095 * \\
(-2.07)\end{array}$ & $\begin{array}{l}-0.096 * \\
(-2.09)\end{array}$ \\
\hline $\begin{array}{l}\text { More than } 1.5 \text { to } 2.5 \\
\text { hours TV }\end{array}$ & $\begin{array}{l}-0.101 * \\
(-2.14)\end{array}$ & $\begin{array}{l}-0.080\left(^{*}\right) \\
(-1.81)\end{array}$ & $\begin{array}{l}-0.104 * \\
(-2.29)\end{array}$ & $\begin{array}{l}-0.096 * \\
(-2.06)\end{array}$ & $\begin{array}{l}-0.083\left(^{*}\right) \\
(-1.78)\end{array}$ & $\begin{array}{l}-0.093 * \\
(-2.03)\end{array}$ & $\begin{array}{l}-0.097 * \\
(-2.09)\end{array}$ \\
\hline $\begin{array}{l}\text { More than } 2.5 \text { hours } \\
\text { TV }\end{array}$ & $\begin{array}{l}-0.183 * * \\
(-3.84)\end{array}$ & $\begin{array}{l}-0.090 * \\
(-1.99)\end{array}$ & $\begin{array}{l}-0.155 * * \\
(-3.37)\end{array}$ & $\begin{array}{l}-0.177^{* *} \\
(-3.71)\end{array}$ & $\begin{array}{l}-0.156 * * \\
(-3.29)\end{array}$ & $\begin{array}{l}-0.156 * * \\
(-3.34)\end{array}$ & $\begin{array}{l}-0.151 * * \\
(-3.20)\end{array}$ \\
\hline \multicolumn{8}{|l|}{ Channels: } \\
\hline Financial satisfaction & & $\begin{array}{l}0.678 * * \\
(47.31)\end{array}$ & $\begin{array}{l}0.759 * * \\
(52.05)\end{array}$ & & & & \\
\hline Importance to be rich & & $\begin{array}{l}-0.038 * * \\
(-4.74)\end{array}$ & & $\begin{array}{l}-0.040 * * \\
(-4.74)\end{array}$ & & & \\
\hline Feeling of safety & & $\begin{array}{l}0.180 * * \\
(13.46)\end{array}$ & & & $\begin{array}{l}0.298 * * \\
(21.57)\end{array}$ & & \\
\hline Trust in people & & $\begin{array}{l}0.129 * * \\
(30.19)\end{array}$ & & & & $\begin{array}{l}0.163 * * \\
(37.46)\end{array}$ & \\
\hline Social Activities & & $\begin{array}{l}0.232 \text { ** } \\
(21.97)\end{array}$ & & & & & $\begin{array}{l}0.307 * * \\
(28.07)\end{array}$ \\
\hline $\begin{array}{l}\text { Socio-demographic } \\
\text { characteristics }\end{array}$ & Yes & Yes & Yes & Yes & Yes & Yes & Yes \\
\hline Country-fixed effects & Yes & Yes & Yes & Yes & Yes & Yes & Yes \\
\hline Observations & & & & 42,021 & & & \\
\hline $\mathrm{R}^{2}$ & 0.18 & 0.26 & 0.22 & 0.18 & 0.19 & 0.20 & 0.20 \\
\hline \multicolumn{8}{|l|}{ t-test Sobel: } \\
\hline 0.5 to 1.5 hours TV & & & 0.34 & $-2.65 *$ & $-3.60 * *$ & -0.78 & -0.74 \\
\hline $\begin{array}{l}\text { More than } 1.5 \text {, up to } 2.5 \\
\text { hours TV }\end{array}$ & & & 0.27 & $-3.72 * *$ & $-3.64 * *$ & -0.84 & -0.49 \\
\hline More than 2.5 hours TV & & & $-2.35 *$ & $-4.15 * *$ & $-5.32 * *$ & $-3.10 * *$ & $-4.86 * *$ \\
\hline
\end{tabular}

Notes:

(1) Channels: Financial satisfaction on scale from 0 to 3, importance to be rich on scale from 0 to 5 , feeling of safety on scale from 0 to 3 , trust in people on scale from 0 to 10, perceived relative frequency of social activities on scale from 0 to 4.

(2) Ordinary least squares estimations.

(4) ** significant on $99 \%$ level, * significant on $95 \%$ level, $(*)$ significant on $90 \%$ level.

(5) t-values in brackets.

(6) Variables for working hours, household income, age, gender, citizenship, marital status, children, education, employment status, location and household size, and dummy variables for highest income category and for the different countries are not shown. Dummy variables for missing observations for financial satisfaction, importance of being rich, feeling of safety, trust in people, social activities, income, household size, working hours, gender, marital status, children, education, employment status, and citizenship are neither shown.

(7) Sobel's t-test for the difference in coefficients with and without intervening variable.

Data Source: European Social Survey, World Development Indicators. 


\section{Appendix}

Table A.1: Summary Statistics

\begin{tabular}{|c|c|c|c|c|c|}
\hline \multirow[t]{2}{*}{ Mean values } & \multirow[b]{2}{*}{$\begin{array}{l}\text { Whole } \\
\text { population }\end{array}$} & \multicolumn{2}{|c|}{$\begin{array}{l}\text { Flexibility of working hours } \\
\text { as distinction criteria }\end{array}$} & \multicolumn{2}{|c|}{$\begin{array}{c}\text { Employment status / } \\
\text { profession as distinction } \\
\text { criteria }\end{array}$} \\
\hline & & $\begin{array}{l}\text { Group with } \\
\text { high } \\
\text { opportunity } \\
\text { costs of time }\end{array}$ & $\begin{array}{c}\text { Group with } \\
\text { low } \\
\text { opportunity } \\
\text { costs of time }\end{array}$ & $\begin{array}{l}\text { Group with } \\
\text { high } \\
\text { opportunity } \\
\text { costs of time }\end{array}$ & $\begin{array}{c}\text { Group with } \\
\text { low } \\
\text { opportunity } \\
\text { costs of time }\end{array}$ \\
\hline Life satisfaction & 7.03 & 7.51 & 6.94 & 7.28 & 6.73 \\
\hline No TV at all & $3.25 \%$ & $3.00 \%$ & $2.79 \%$ & $3.73 \%$ & $2.72 \%$ \\
\hline Less than 0.5 hour TV & $5.61 \%$ & $6.86 \%$ & $6.20 \%$ & $8.66 \%$ & $2.82 \%$ \\
\hline 0.5 to 1.5 hours TV & $29.21 \%$ & $38.59 \%$ & $32.98 \%$ & $40.71 \%$ & $18.35 \%$ \\
\hline More than 1.5 to 2.5 hours TV & $29.34 \%$ & $31.47 \%$ & $32.44 \%$ & $27.90 \%$ & $26.96 \%$ \\
\hline More than 2.5 hours TV & $32.59 \%$ & $20.08 \%$ & $25.59 \%$ & $19.01 \%$ & $49.15 \%$ \\
\hline Working hours & 18.87 & 39.20 & 38.35 & 41.03 & 0 \\
\hline Household income (EUR, PPP) & 1956.53 & 2919.68 & 2065.86 & 2879.43 & 1313.70 \\
\hline Age & 46.18 & 40.96 & 39.44 & 43.50 & 64.32 \\
\hline Male & $47.37 \%$ & $58.22 \%$ & $55.10 \%$ & $65.04 \%$ & $50.91 \%$ \\
\hline Female & $52.51 \%$ & $41.75 \%$ & $44.80 \%$ & $34.89 \%$ & $49.03 \%$ \\
\hline Foreigner & $2.76 \%$ & $2.43 \%$ & $4.66 \%$ & $3.64 \%$ & $2.36 \%$ \\
\hline Citizen of country & $96.00 \%$ & $95.63 \%$ & $94.21 \%$ & $96.27 \%$ & $97.47 \%$ \\
\hline Married, living with partner & $53.89 \%$ & $58.28 \%$ & $56.23 \%$ & $63.75 \%$ & $52.51 \%$ \\
\hline Married, not living with partner & $0.39 \%$ & $0.42 \%$ & $0.40 \%$ & $0.39 \%$ & $0.59 \%$ \\
\hline Separated, living with partner & $0.27 \%$ & $0.43 \%$ & $0.31 \%$ & $0.45 \%$ & $0.13 \%$ \\
\hline Separated, not living with partner & $1.22 \%$ & $1.24 \%$ & $1.36 \%$ & $1.31 \%$ & $1.01 \%$ \\
\hline Divorced, living with partner & $1.53 \%$ & $2.31 \%$ & $1.90 \%$ & $2.13 \%$ & $1.17 \%$ \\
\hline Divorced, not living with partner & $5.00 \%$ & $5.63 \%$ & $5.69 \%$ & $4.54 \%$ & $5.64 \%$ \\
\hline Widowed, living with partner & $0.42 \%$ & $0.14 \%$ & $0.08 \%$ & $0.10 \%$ & $1.04 \%$ \\
\hline Widowed, not living with partner & $8.58 \%$ & $1.33 \%$ & $1.53 \%$ & $1.85 \%$ & $24.41 \%$ \\
\hline $\begin{array}{l}\text { Never been married, living with } \\
\text { partner }\end{array}$ & $5.94 \%$ & $10.31 \%$ & $8.51 \%$ & $7.55 \%$ & $1.48 \%$ \\
\hline $\begin{array}{l}\text { Never been married, not living with } \\
\text { partner }\end{array}$ & $22.28 \%$ & $19.50 \%$ & $23.45 \%$ & $17.48 \%$ & $11.72 \%$ \\
\hline Children living at home & $40.07 \%$ & $49.94 \%$ & $49.25 \%$ & $51.82 \%$ & $20.60 \%$ \\
\hline Not completed primary education & $3.91 \%$ & $0.43 \%$ & $1.19 \%$ & $1.09 \%$ & $8.76 \%$ \\
\hline $\begin{array}{l}\text { Primary or first stage of basic } \\
\text { education }\end{array}$ & $13.27 \%$ & $4.66 \%$ & $8.09 \%$ & $7.08 \%$ & $22.44 \%$ \\
\hline $\begin{array}{l}\text { Lower secondary or second stage of } \\
\text { basic education }\end{array}$ & $22.68 \%$ & $15.96 \%$ & $22.34 \%$ & $12.50 \%$ & $24.86 \%$ \\
\hline Upper secondary education & $32.48 \%$ & $35.45 \%$ & $37.75 \%$ & $24.29 \%$ & $27.03 \%$ \\
\hline $\begin{array}{l}\text { Post secondary, non-tertiary } \\
\text { education }\end{array}$ & $8.30 \%$ & $10.88 \%$ & $10.24 \%$ & $9.53 \%$ & $5.14 \%$ \\
\hline
\end{tabular}

Table to be continued 
Continuation of table A1

\begin{tabular}{lccccc}
\hline First stage of tertiary education & $12.92 \%$ & $21.30 \%$ & $13.21 \%$ & $28.92 \%$ & $8.08 \%$ \\
Second stage of tertiary education & $5.72 \%$ & $11.01 \%$ & $6.68 \%$ & $16.22 \%$ & $3.26 \%$ \\
Paid work, employed & $40.47 \%$ & $100.00 \%$ & $100.00 \%$ & $50.99 \%$ & $0.00 \%$ \\
Paid work, self-employed & $8.18 \%$ & $0.00 \%$ & $0.00 \%$ & $49.01 \%$ & $0.00 \%$ \\
Unemployed, looking for a job & $2.90 \%$ & $0.00 \%$ & $0.00 \%$ & $0.00 \%$ & $11.52 \%$ \\
Unemployed, not looking for a job & $1.43 \%$ & $0.00 \%$ & $0.00 \%$ & $0.00 \%$ & $5.95 \%$ \\
Education & $8.16 \%$ & $0.00 \%$ & $0.00 \%$ & $0.00 \%$ & $0.00 \%$ \\
Permanently sick or disabled & $2.02 \%$ & $0.00 \%$ & $0.00 \%$ & $0.00 \%$ & $0.00 \%$ \\
Retired & $20.12 \%$ & $0.00 \%$ & $0.00 \%$ & $0.00 \%$ & $82.53 \%$ \\
Community or military service & $0.32 \%$ & $0.00 \%$ & $0.00 \%$ & $0.00 \%$ & $0.00 \%$ \\
Housework, looking after children & $11.76 \%$ & $0.00 \%$ & $0.00 \%$ & $0.00 \%$ & $0.00 \%$ \\
Big city & $18.51 \%$ & $17.35 \%$ & $19.54 \%$ & $20.30 \%$ & $18.25 \%$ \\
Suburbs & $14.36 \%$ & $18.68 \%$ & $13.04 \%$ & $15.48 \%$ & $13.62 \%$ \\
Town, small city & $29.20 \%$ & $28.31 \%$ & $31.56 \%$ & $26.49 \%$ & $30.30 \%$ \\
Country village & $31.04 \%$ & $28.95 \%$ & $29.89 \%$ & $28.50 \%$ & $31.28 \%$ \\
Farm, home in countryside & $6.43 \%$ & $6.42 \%$ & $5.54 \%$ & $8.99 \%$ & $6.21 \%$ \\
\hline Observations & 42,021 & 6,460 & 7,062 & 5,950 & 8,974 \\
\hline Data source: European Social Survey, World Development Indicators & & \\
\hline
\end{tabular}


Table A.2: Television Consumption and Life Satisfaction: Opportunity Costs of Time

\begin{tabular}{|c|c|c|c|c|}
\hline \multirow[t]{2}{*}{$\begin{array}{l}\text { Dependent variable: } \\
\text { Life satisfaction }\end{array}$} & \multicolumn{2}{|c|}{$\begin{array}{l}\text { Flexibility of working hours as } \\
\text { distinction criteria }\end{array}$} & \multicolumn{2}{|c|}{$\begin{array}{l}\text { Employment status / profession as } \\
\text { distinction criteria }\end{array}$} \\
\hline & $\begin{array}{l}\text { Group with high } \\
\text { opportunity } \\
\text { costs of time } \\
\end{array}$ & $\begin{array}{l}\text { Group with low } \\
\text { opportunity costs } \\
\text { of time }\end{array}$ & $\begin{array}{c}\text { Group with high } \\
\text { opportunity costs } \\
\text { of time }\end{array}$ & $\begin{array}{c}\text { Group with low } \\
\text { opportunity costs } \\
\text { of time }\end{array}$ \\
\hline No TV at all & $\begin{array}{l}-0.355 * \\
(-2.33)\end{array}$ & $\begin{array}{r}0.056 \\
(0.33)\end{array}$ & $\begin{array}{l}-0.238 \\
(-1.58)\end{array}$ & $\begin{array}{l}-0.251 \\
(-1.24)\end{array}$ \\
\hline Less than 0.5 hour TV & \multicolumn{4}{|c|}{ Reference group } \\
\hline 0.5 to 1.5 hours TV & $\begin{array}{l}-0.328 * * \\
(-3.59)\end{array}$ & $\begin{array}{l}-0.072 \\
(-0.69)\end{array}$ & $\begin{array}{l}-0.074 \\
(-0.80)\end{array}$ & $\begin{array}{l}-0.105 \\
(-0.70)\end{array}$ \\
\hline $\begin{array}{l}\text { More than } 1.5 \text { to } 2.5 \text { hours } \\
\text { TV }\end{array}$ & $\begin{array}{l}-0.339 * * \\
(-3.62)\end{array}$ & $\begin{array}{l}-0.041 \\
(-0.38)\end{array}$ & $\begin{array}{l}-0.229 * \\
(-2.38)\end{array}$ & $\begin{array}{r}0.052 \\
(0.35)\end{array}$ \\
\hline More than 2.5 hours TV & $\begin{array}{l}-0.377 * * \\
(-3.78)\end{array}$ & $\begin{array}{l}-0.140 \\
(-1.28)\end{array}$ & $\begin{array}{l}-0.389 * * \\
(-3.76)\end{array}$ & $\begin{array}{l}-0.012 \\
(-0.08)\end{array}$ \\
\hline Working hours & $\begin{array}{r}0.004 \\
(0.72)\end{array}$ & $\begin{array}{r}0.008 \\
(1.17)\end{array}$ & $\begin{array}{l}0.014 * \\
(2.46)\end{array}$ & \\
\hline Working hours, squared & $\begin{array}{r}-0.00005 \\
(-0.81)\end{array}$ & $\begin{array}{l}-0.0002 * \\
(-1.94)\end{array}$ & $\begin{array}{l}-0.0002 * * \\
(-3.26)\end{array}$ & \\
\hline $\begin{array}{l}\text { Household income (EUR, } \\
\text { PPP) }\end{array}$ & $\begin{array}{l}0.326 * * \\
(7.69)\end{array}$ & $\begin{array}{l}0.363 * * \\
(8.27)\end{array}$ & $\begin{array}{l}0.385 * * \\
(8.77)\end{array}$ & $\begin{array}{l}0.339 * * \\
(8.52)\end{array}$ \\
\hline Age & $\begin{array}{l}-0.062 * * \\
(-4.45)\end{array}$ & $\begin{array}{l}-0.067 * * \\
(-4.33)\end{array}$ & $\begin{array}{l}-0.083 * * \\
(-5.22)\end{array}$ & $\begin{array}{l}-0.092 * * \\
(-8.27)\end{array}$ \\
\hline Age, squared & $\begin{array}{l}0.0007^{* *} \\
(4.14)\end{array}$ & $\begin{array}{l}0.0007 * * \\
(4.00)\end{array}$ & $\begin{array}{l}0.0008 * * \\
(4.73)\end{array}$ & $\begin{array}{l}0.0008 * * \\
(8.90)\end{array}$ \\
\hline Male & \multicolumn{4}{|c|}{ Reference group } \\
\hline Female & $\begin{array}{r}0.034 \\
(0.71)\end{array}$ & $\begin{array}{l}0.190 * * \\
(3.71)\end{array}$ & $\begin{array}{l}0.154^{* *} \\
(2.87)\end{array}$ & $\begin{array}{l}0.130 * \\
(2.55)\end{array}$ \\
\hline Foreigner & \multicolumn{4}{|c|}{ Reference group } \\
\hline Citizen of country & $\begin{array}{l}0.320 * * \\
(2.71)\end{array}$ & $\begin{array}{l}0.241 * \\
(2.15)\end{array}$ & $\begin{array}{l}0.227(*) \\
(1.69)\end{array}$ & $\begin{array}{l}0.275(*) \\
(1.71)\end{array}$ \\
\hline Married, living with partner & \multicolumn{4}{|c|}{ Reference group } \\
\hline $\begin{array}{l}\text { Married, not living with } \\
\text { partner }\end{array}$ & $\begin{array}{l}-0.971 * * \\
(-2.84)\end{array}$ & $\begin{array}{l}-0.574 \\
(-1.50)\end{array}$ & $\begin{array}{l}-0.314 \\
(-0.80)\end{array}$ & $\begin{array}{l}-1.112 * * \\
(-3.26)\end{array}$ \\
\hline Separated, living with partner & $\begin{array}{l}-0.110 \\
(-0.33)\end{array}$ & $\begin{array}{l}-0.500 \\
(-1.17)\end{array}$ & $\begin{array}{l}-0.274 \\
(-0.76)\end{array}$ & $\begin{array}{l}0.155 \\
(0.24)\end{array}$ \\
\hline $\begin{array}{l}\text { Separated, not living with } \\
\text { partner }\end{array}$ & $\begin{array}{l}-0.667 * * \\
(-3.30)\end{array}$ & $\begin{array}{l}-0.978 * * \\
(-4.67)\end{array}$ & $\begin{array}{l}-1.004 * * \\
(-4.60)\end{array}$ & $\begin{array}{l}-0.999 * * \\
(-4.13)\end{array}$ \\
\hline Divorced, living with partner & $\begin{array}{l}-0.113 \\
(-0.76)\end{array}$ & $\begin{array}{l}-0.421 * \\
(-2.37)\end{array}$ & $\begin{array}{l}-0.259 \\
(-1.52)\end{array}$ & $\begin{array}{l}-0.530 * * \\
(-2.39)\end{array}$ \\
\hline $\begin{array}{l}\text { Divorced, not living with } \\
\text { partner }\end{array}$ & $\begin{array}{l}-0.306 * * \\
(-2.94)\end{array}$ & $\begin{array}{l}-0.549 * * \\
(-4.96)\end{array}$ & $\begin{array}{l}-0.641 * * \\
(-5.09)\end{array}$ & $\begin{array}{l}-0.501 * * \\
(-4.35)\end{array}$ \\
\hline Widowed, living with partner & $\begin{array}{l}-0.388 \\
(-0.66)\end{array}$ & $\begin{array}{l}-1.714 * \\
(-2.10)\end{array}$ & $\begin{array}{l}-2.180 * * \\
(-2.86)\end{array}$ & $\begin{array}{l}-0.230 \\
(-0.98)\end{array}$ \\
\hline $\begin{array}{l}\text { Widowed, not living with } \\
\text { partner }\end{array}$ & $\begin{array}{l}-0.541 * * \\
(-2.73)\end{array}$ & $\begin{array}{l}-0.940 * * \\
(-4.68)\end{array}$ & $\begin{array}{l}-0.544(*) \\
(2.89)\end{array}$ & $\begin{array}{l}-0.407 * * \\
(-5.19)\end{array}$ \\
\hline $\begin{array}{l}\text { Never been married, living } \\
\text { with partner }\end{array}$ & $\begin{array}{l}-0.102 * * \\
(-1.21)\end{array}$ & $\begin{array}{l}-0.105 \\
(-1.08)\end{array}$ & $\begin{array}{l}-0.198\left(^{*}\right) \\
(-1.92)\end{array}$ & $\begin{array}{l}-0.270 \\
(-1.32)\end{array}$ \\
\hline $\begin{array}{l}\text { Never been married, not } \\
\text { living with partner }\end{array}$ & $\begin{array}{l}-0.373 * * \\
(-4.72)\end{array}$ & $\begin{array}{l}-0.470 * * \\
(-5.92)\end{array}$ & $\begin{array}{l}-0.535^{* *} \\
(-6.20)\end{array}$ & $\begin{array}{l}-0.691 * * \\
(-7.17)\end{array}$ \\
\hline No children at home & \multicolumn{4}{|c|}{ Reference group } \\
\hline Children living at home & $\begin{array}{l}-0.069 \\
(-1.01)\end{array}$ & $\begin{array}{l}-0.169 * \\
(-2.30)\end{array}$ & $\begin{array}{l}-0.131(*) \\
(-1.71)\end{array}$ & $\begin{array}{l}-0.291 * * \\
(-3.38)\end{array}$ \\
\hline
\end{tabular}


Continuation of table A2

\begin{tabular}{|c|c|c|c|c|}
\hline $\begin{array}{l}\text { Not completed primary } \\
\text { education }\end{array}$ & $\begin{array}{r}0.020 \\
(0.06)\end{array}$ & $\begin{array}{l}-0.149 \\
(-0.63)\end{array}$ & $\begin{array}{l}-0.110 \\
(-0.44)\end{array}$ & $\begin{array}{l}-0.433 * * \\
(-4.39)\end{array}$ \\
\hline $\begin{array}{l}\text { Primary or first stage of basic } \\
\text { education }\end{array}$ & \multicolumn{4}{|c|}{ Reference group } \\
\hline $\begin{array}{l}\text { Lower secondary or second } \\
\text { stage of basic education }\end{array}$ & $\begin{array}{r}0.133 \\
(1.10)\end{array}$ & $\begin{array}{r}0.142 \\
(1.35)\end{array}$ & $\begin{array}{l}0.202(*) \\
(1.69)\end{array}$ & $\begin{array}{r}0.075 \\
(0.97)\end{array}$ \\
\hline Upper secondary education & $\begin{array}{r}0.147 \\
(1.27)\end{array}$ & $\begin{array}{l}0.198(*) \\
(1.92)\end{array}$ & $\begin{array}{l}0.263 * \\
(2.30)\end{array}$ & $\begin{array}{l}0.160 * \\
(1.98)\end{array}$ \\
\hline $\begin{array}{l}\text { Post secondary, non-tertiary } \\
\text { education }\end{array}$ & $\begin{array}{r}0.195 \\
(1.50)\end{array}$ & $\begin{array}{l}0.277 * \\
(2.24)\end{array}$ & $\begin{array}{l}0.292 * \\
(2.17)\end{array}$ & $\begin{array}{l}0.415 * * \\
(3.34)\end{array}$ \\
\hline $\begin{array}{l}\text { First stage of tertiary } \\
\text { education }\end{array}$ & $\begin{array}{r}0.175 \\
(1.44)\end{array}$ & $\begin{array}{l}0.435 * * \\
(3.72)\end{array}$ & $\begin{array}{l}0.256 * \\
(2.12)\end{array}$ & $\begin{array}{l}0.290 * * \\
(2.71)\end{array}$ \\
\hline $\begin{array}{l}\text { Second stage of tertiary } \\
\text { education }\end{array}$ & $\begin{array}{r}0.209 \\
(1.62)\end{array}$ & $\begin{array}{l}0.442 * * \\
(3.28)\end{array}$ & $\begin{array}{l}0.167 \\
(1.27)\end{array}$ & $\begin{array}{l}0.600 * * \\
(4.07)\end{array}$ \\
\hline $\begin{array}{l}\text { Paid work, employed } \\
\text { Paid work, self-employed }\end{array}$ & \multicolumn{4}{|c|}{$\begin{array}{c}\text { Reference group } \\
-0.131 * \\
(-2.09)\end{array}$} \\
\hline Retired & & & & Reference group \\
\hline $\begin{array}{l}\text { Unemployed, looking for a } \\
\text { job }\end{array}$ & & & & $\begin{array}{l}-1.476 * * \\
(-12.37)\end{array}$ \\
\hline $\begin{array}{l}\text { Unemployed, not looking for } \\
\text { a job }\end{array}$ & & & & $\begin{array}{l}-1.015 * * \\
(-7.75)\end{array}$ \\
\hline Big city & \multicolumn{4}{|c|}{ Reference group } \\
\hline Suburbs & $\begin{array}{l}0.064 \\
(0.84)\end{array}$ & $\begin{array}{l}0.149(*) \\
(1.70)\end{array}$ & $\begin{array}{l}-0.048 \\
(-0.57)\end{array}$ & $\begin{array}{r}0.045 \\
(0.52)\end{array}$ \\
\hline Town, small city & $\begin{array}{r}0.047 \\
(0.69)\end{array}$ & $\begin{array}{l}0.230 * * \\
(3.20)\end{array}$ & $\begin{array}{l}-0.033 \\
(-0.44)\end{array}$ & $\begin{array}{l}0.082 \\
(1.13)\end{array}$ \\
\hline Country village & $\begin{array}{l}0.145 * \\
(2.05)\end{array}$ & $\begin{array}{l}0.266 * * \\
(3.58)\end{array}$ & $\begin{array}{r}0.105 \\
(1.39)\end{array}$ & $\begin{array}{l}0.285 * * \\
(3.91)\end{array}$ \\
\hline Farm, home in countryside & $\begin{array}{l}0.368 \text { ** } \\
(3.45)\end{array}$ & $\begin{array}{l}0.288 * \\
(2.32)\end{array}$ & $\begin{array}{l}0.281 * \\
(2.54)\end{array}$ & $\begin{array}{l}0.401 * * \\
(3.35)\end{array}$ \\
\hline Country-fixed effects & Yes & Yes & Yes & Yes \\
\hline Constant & $\begin{array}{c}6.203 * * \\
(12.39)\end{array}$ & $\begin{array}{c}5.895^{* *} \\
(10.22)\end{array}$ & $\begin{array}{c}6.204 \text { ** } \\
(10.94)\end{array}$ & $\begin{array}{c}6.919 * * \\
(11.93)\end{array}$ \\
\hline Observations & 6,460 & 7,062 & 5,950 & 8,974 \\
\hline $\mathrm{R}^{2}$ & 0.14 & 0.15 & 0.16 & 0.22 \\
\hline
\end{tabular}

Notes:

(1) Group 1 contains respondents with flexibility of working hours of 6 and higher on a scale from 0 to 10 and group 2 the people with flexibility of working hours of 5 and lower. In both groups, respondents' employment status is "paid work, employed" and nothing else. Group 3 contains the self-employed, as well as managers, senior officials, legislators and professionals (according to ISCO-88 classification) with employment status "paid work" (employed or self-employed) and nothing else and group 4 contains retirees and the unemployed with no other employment status.

(2) Ordinary least squares estimations.

(3) ** significant at 99\% level, * significant at 95\% level, (*) significant at 90\% level.

(4) t-values in brackets.

(5) Variable for household size and dummy variables for highest income category and for the different countries are not shown. Dummy variables for missing observations for income, household size, working hours, gender, marital status, children, education, employment status, and citizenship are neither shown.

Data Source: European Social Survey, World Development Indicators. 